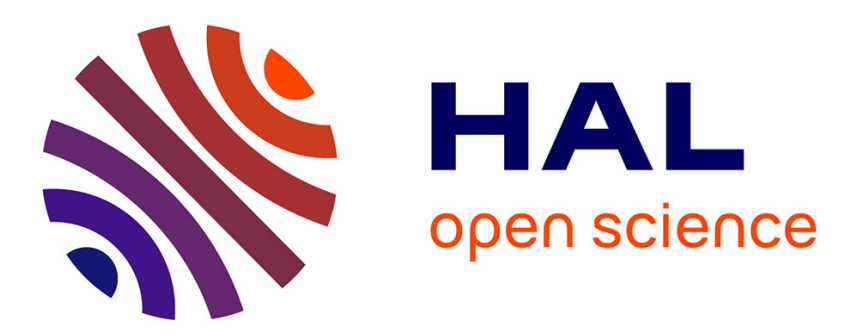

\title{
Integrative taxonomy of the Clavus canalicularis species complex (Drilliidae, Conoidea, Gastropoda) with description of four new species
}

\author{
A. E Fedosov, N. Puillandre
}

\section{- To cite this version:}

A. E Fedosov, N. Puillandre. Integrative taxonomy of the Clavus canalicularis species complex (Drilliidae, Conoidea, Gastropoda) with description of four new species. Molluscan Research, 2020, 40 (3), pp.251-266. 10.1080/13235818.2020.1788695 . hal-02975080

\author{
HAL Id: hal-02975080 \\ https://hal.science/hal-02975080
}

Submitted on 22 Oct 2020

HAL is a multi-disciplinary open access archive for the deposit and dissemination of scientific research documents, whether they are published or not. The documents may come from teaching and research institutions in France or abroad, or from public or private research centers.
L'archive ouverte pluridisciplinaire HAL, est destinée au dépôt et à la diffusion de documents scientifiques de niveau recherche, publiés ou non, émanant des établissements d'enseignement et de recherche français ou étrangers, des laboratoires publics ou privés. 
Integrative taxonomy of the Clavus canalicularis species complex (Drilliidae, Conoidea, Gastropoda) with description of four new species

A.E. Fedosov ${ }^{1}$, N. Puillandre ${ }^{2}$

${ }^{1}$ A.N. Severtsov Institute of Ecology and Evolution, Russian Academy of Sciences, Leninsky prospect 33, 119071, Moscow, Russian Federation

${ }^{2}$ Institut Systématique Evolution Biodiversité (ISYEB), Muséum National d'Histoire Naturelle, CNRS, Sorbonne Université, EPHE, Université des Antilles, 57 rue Cuvier, CP 26, 75005 Paris, France

\begin{abstract}
The conoidean family Drilliidae Olsson, 1964 is a species-rich lineage of marine gastropods, showing a high degree of diversification even in comparison to other families of Conoidea. Despite intensive molecular phylogenetic studies during the last decade that have led to notable rearrangements of conoidean systematics, the genus- and species-level taxonomy of Drilliidae has not thus far been affected and remains entirely based on shell features. In the current study we revisit species delimitation in a morphological cluster of species from the Indo- Pacific referred to as the Clavus canalicularis complex, using an integrative taxonomy approach. The species in the complex possess robust thick-walled shells typically over $15 \mathrm{~mm}$ in height with sculpture of prominent rounded nodules located at the whorl's shoulder, sometimes sharp and squamiform, or producing long spines. We find that the complex comprises in addition to five known species, four new species. These are described as Clavus brianmayi n. sp. (New Caledonia), Clavus davidgilmouri n. sp. (the Philippines), Clavus andreolbrichi n. sp. (Vanuatu and New Ireland) and Clavus kirkhammetti n. sp. (Madagascar). Clavus exasperatus (Reeve, 1843), which was previously considered widely distributed in Indo-Pacific, is shown to be confined to the western Indian Ocean.
\end{abstract}

\title{
Key words
}

Conoidea, Drilliidae, species complex, COI. 


\section{Introduction}

The conoidean family Drilliidae Olsson, 1964 is a species-rich lineage of marine gastropods, showing a high degree of diversification even in comparison to other families of the superfamily Conoidea (Bouchet et al. 2011; Fallon, 2016; Abdelkrim et al. 2018). The family is mainly confined to the tropical waters, where it reaches high diversity in both the Atlantic Ocean and Indo-West Pacific. Drilliidae is distinctive among Conoidea in having a peculiar radula with wide comb-like lateral teeth (Powell 1966; McLean 1971; Sysoev and Kantor 1989; Taylor et al. 1993), a feature highly conserved across the family and allowing its unequivocal circumscription. The morphological distinctiveness of the drilliid radula, its apomorphic status (according to a recent reconstructions of conoidean phylogeny - Abdelkrim et al. 2018), and its conservation within the family - all point at certain functional advantages of comb-like lateral teeth, which likely should be sought in their feeding mechanism. Like most other conoideans, Drilliidae possess a venom gland; however, the mechanism of venom delivery known from conesnails, i.e. the use of the marginal tooth transformed into a hollow harpoon (Olivera et al. 2017) is not available to Drilliidae because their marginal teeth are flat and do not possess an enclosed channel (Sysoev and Kantor 1989). A recent analysis of the venom gland transcriptome of two drilliid species of the genus Clavus Montfort, 1810 revealed high expression levels of peptides with known cytolytic functions (which are likely to facilitate envenomation), and an unprecedented diversity of short conotoxin-like peptides drillipeptides (Lu et al. 2020). The latter finding and the demonstrated bioactivity of the predicted drillipeptide $c d g 14 a$ in vertebrate system (Chua et al. submitted) call for future investigation of the drilliid venoms, from the prospective of both venom evolution and drug development. Nevertheless, efficient characterisation of drilliid venoms is presently hampered by the problematic taxonomy of Drilliidae.

The generic composition of Drilliidae did not change much in the course of the recent turbulent reorganisation of conoidean systematics (Taylor et al. 1993; Bouchet et al. 2011; Abdelkrim et al. 2018). Boundaries of most genera remain poorly defined, and have never been addressed with the use of molecular approaches. Likewise, the species level taxonomy of Drilliidae is entirely built on conchological characters, as not a single species of the family has been erected in association with molecular data. Meanwhile, the application of molecular approaches to species delimitation in Conoidea tends to notably modify original conchology-based species hypotheses (e.g. Puillandre et al. 2009; Fedosov et al. 2017; Kantor et al. 2017; Zaharias et al. 2020), leading to a strong recommendation to avoid whenever possible the description of new Conoidean species unless supported by molecular data (Puillandre et al. 2017; Zaharias et al. 
2020). In this context rarity of application of DNA sequence data to drilliid taxonomy not only leads to uncertainty in specimen allocation to species, but also makes the current estimates of the family's species diversity (in particular, those used in the analysis of Abdelkrim et al. 2018) doubtful.

In the present study, we revisit species delimitation in the Clavus canalicularis (Röding, 1798) complex based on the molecular phylogenetic analysis of partial COI sequences, reevaluate morphological circumscription of the species, and provide taxonomic treatments of newly identified species. The Indo-Pacific genus Clavus comprises a diversity of forms, varying in size, shell proportions and sculpture. Within the genus, the morphologically-defined Clavus canalicularis species complex is distinguishable by the rather large thick walled shell, with strongly-pronounced, often squamiform sculptural elements. Four species are currently recognised in the complex: Clavus canalicularis (Röding, 1798), C. exasperatus (Reeve, 1843), C. rugizonatus Hervier, 1896 and C. devexistriatus Kilburn, Fedosov \& Kantor, 2014. The first two are distributed throughout the IWP and are represented by various morphs, the status of which is uncertain. In contrast the latter two species are known mainly from New Caledonia, and their species status also requires confirmation. Our analysis revealed three new species in this complex, as well as one new species that does not share the aforementioned characteristics, despite being phylogenetically closely related to C. exasperatus. The shell morphology revisited with the guidance of the molecular phylogenetic tree revealed combinations of characters that are unique for each species and allow their unmistakable identification. 


\section{Material and Methods}

\section{Material}

Material for the present study was collected during several expeditions organised by the MNHN (Muséum National d'Histoire Naturelle, Paris, France) in the Indo-Pacific: PANGLAO 2004 in the Philippines, SANTO 2006 in Vanuatu, ATIMO-VATAE in Southern Madagascar (doi.org/10.17600/10110040), INHACA 2011 in Mozambique, KAVIENG 2014 in Papua-NewGuinea (doi.org/10.17600/14004400) and KOUMAC 2.1 in New Caledonia (2018). Prior to 2012, live specimens for molecular studies were anaesthetised with an isotonic solution of $\mathrm{MgCl}_{2}$ and tissue clips were fixed in $96 \%$ ethanol. Specimens collected in the later expeditions were processed with a microwave oven (Galindo et al. 2014): live molluscs were exposed to microwaves for 7-30 seconds, depending on specimen size. Then bodies were immediately extracted from shells, tissue-clipped and preserved in 96\% ethanol. All sequenced specimens are deposited in the MNHN collections. Specimen data and sequences are deposited in BOLD (Barcode of Life Datasystem) and GenBank (Table 1).

<insert Table 1>

DNA sequencing

DNA was extracted using a epMotion 5075 robot (Eppendorf), following the manufacturer's recommendations. For a set of additional samples, DNA was extracted using a KingFisher Flex (Thermo Fisher Scientific) robot with InviMag Tissue DNA kit/ KF96 following the manufacturer's protocol. A barcode fragment of the cytochrome oxidase subunit I (COI) was amplified using universal primers LCO1490/HCO2198 (Folmer et al. 1994). PCR reactions were performed in $20 \mu \mathrm{l}$, containing $3 \mathrm{ng}$ of DNA, $1 \mathrm{X}$ reaction buffer, $2.5 \mathrm{mM} \mathrm{MgCl} 2,0.26 \mathrm{mM}$ dNTP, $0.3 \mathrm{mM}$ of each primer, 5\% DMSO, 5\% BSA and 1.5 units of Qbiogene Q-Bio Taq. In all cases the COI amplification included an initial denaturation step at $94^{\circ} \mathrm{C}$ for $5 \mathrm{~min}$, followed by 35 cycles of denaturation at $94^{\circ} \mathrm{C}$ for $30 \mathrm{~s}$, annealing at $50^{\circ} \mathrm{C}$ for $30 \mathrm{~s}$, and extension at $72^{\circ} \mathrm{C}$ for $45 \mathrm{~s}$, followed by the final extension phase of $7 \mathrm{~min}$ at $72^{\circ} \mathrm{C}$. The success of the PCR reactions was checked by gel electrophoresis, then PCR products were purified and sequenced in both directions by the Eurofins sequencing facility or with the Applied Biosystem 3100 sequencer in the joint usage center 'Instrumental methods in Ecology' in the IEE RAS.

\section{Species delimitation}

The sequenced specimens were sorted by morphospecies to constitute a first set of primary species hypotheses (PSHs), based on shell morphology, following Kilburn (1988), Kilburn et al. (2014) and Sysoev (2008). Then, the ABGD method was applied to the COI dataset to propose 
an independent set of PSHs. Then, morphology based species hypotheses and COI based species hypotheses were compared and discussed using additional data and criteria, i.e. the (non)monophyly of the PSH as inferred using a phylogenetic approach based on the COI gene, and the geographic distribution patterns, making up the final set of secondary species hypotheses (SSHs). Finally, the relevant type specimens were studied to apply names to the SSHs.

The original COI sequences were supplemented by two COI sequences of Clavus from GenBank (JF823616.1 and JF823618.1 - Cabang et al. 2011); two other Clavus spp. sequences in GenBank were not included in the analysis because they do not belong to the $C$. canalicularis species complex (JF823617.1; JF823619.1). Sequences were aligned manually; pairwise genetic K2P distances were calculated using MEGA 6 (Tamura et al. 2013). The web version of ABGD (http://wwwabi.snv.jussieu.fr/public/abgd) with default parameters was applied to propose sets of species partitions (Puillandre et al. 2012). For the phylogenetic analysis, sequences of the Clavus canalicularis species complex were supplemented by sequences of Drilliidae species Iredalea pupoidea (H. Adams, 1872) MNHN-IM-2007-42556, Syntomodrillia carolinae Bartsch, 1934 MNHN-IM-2013-9019, and Splendrillia sp. MNHN-IM-2007-17886, which were used as outgroups, based on the topology of the Drilliidae segment of the tree in Puillandre et al. (2011), as well, as three specimens of 'Clavus' obliquecostatus Kilburn, Fedosov, Kantor, 2014, a species morphologically divergent from the C. canalicularis complex.

The maximum likelihood trees were reconstructed using RaxML v8.2.8 (Stamatakis 2006), with the robustness of the nodes estimated by using 1,000 bootstraps, and by IQ-tree v.1.6.3 (Nguyen et al. 2014) with nodal support estimated by 1000 pseudo-iterations of ultra-fast bootstraps. The COI gene was divided into three partitions corresponding to the three codon positions and a GTR+I+G substitution model was used for the three partitions independently, as identified by Partition Finder (Lanfear et al. 2017). Bayesian inference (Huelsenbeck et al. 2001) was performed using MrBayes, by running two parallel analyses, consisting each of six Markov chains for 20,000,000 generations with a sampling frequency of one tree each 1,000 generations, a chain temperature of 0.02 , and the parameters of the substitution model estimated during the analysis (6 substitution categories, a gamma-distributed rate variation across sites approximated in four discrete categories and a proportion of invariable sites). Trees from first 5,000,000 generations ( $25 \%$ from total number of generations) were discarded as burn in prior to the construction of the consensus trees. Convergence of each analysis was evaluated using Tracer 1.4.1 (Rambaut et al. 2014) by checking that ESS values all exceeded 200. IQ-tree was run locally, and the RAxML and Bayesian inference were performed at Cipres Gateway (Miller et al. 2010), using RAxML-HPC on XSEDE and MrBayes 2.3.7 on XSEDE tools respectively. 
Abbreviations of museums and repositories

MNHN - Muséum National d'Histoire Naturelle, Paris, France.

MHNG - Muséum National d'Histoire Naturelle, Geneva, Swiss.

NMSA - Natal Museum of South Africa, Pietermaritzburg, South Africa.

NHMUK - The Natural History Museum of UK, London, UK.

ZSI - Zoological survey of India, Kolkata, India.

Other abbreviations:

dd - dead specimens

IWP - Indo-West Pacific

lv - live specimens 


\section{Results}

Species delimitation and phylogenetic analysis

Initially studied specimens of the $C$. canalicularis complex were sorted into four putative species based on the gross shell morphology. The specimens with spinose, often notably elongated nodules, rough, often dark shell base to sometimes uniformly brown shells, were tentatively placed in Clavus canalicularis. The specimens with an overall light spire, weaker nodules and an orange to brown band on the shell base were tentatively placed in either $C$. rugizonatus (shell base with minute rounded nodules arranged in spiral rows) or in C. exasperatus (shell base smooth, or with prevailing spiral elements). Five specimens from South Madagascar were attributed to a fourth morphological cluster, as they were notably different from the rest of studied material in having more glossy shells with depressed subsutural band, and low, rounded ribs extended axially. These morphological clusters were assigned letters A-D to compare with the COI based species hypotheses.

<insert Figure 1>

The ABGD run resulted in a partition scheme comprising seven PSH within the Clavus canalicularis complex (Figure 1). The eight Clavus specimens from the western Indian Ocean (ATIMO VATAE and INHACA 2011) composed the first and second ABGD PSHs (marked with yellow and pink circles on Figure 1), and the remaining five partitions comprised specimens from the Central Indo-Pacific (with light-blue, dark-blue, green and purple circles; for distributions see Figure 2). The third PSH comprised five specimens from Vanuatu and New Ireland. The fourth and fifth PSHs corresponded to groups of specimens with restricted distribution, from off Koumac in New Caledonia and from the Central Philippines respectively. The largest PSH, the sixth, included 23 specimens from the Central Philippines, New Ireland and New Caledonia, and the seventh PSH included specimens from New Ireland exclusively (Figure 2).

The COI phylogenetic trees based on Bayesian analysis, IQtree and RaxML were congruent in all nodes, with well-supported terminal clades (RAxML bootstrap >82, IQ-tree UF-bootstrap $>98$, Bayesian posterior probability 1) recovered for all ABGD-based PSHs except the heterogeneous PSH 6 (Figure 1). The latter corresponds to a grade, including the specimens of the ABGD PSH 7. The maximum K2P genetic distances within the inferred clades varied from $0.3 \%$ (in the ABGD PSH 7) to 2\% (between two specimens of the ABGD PSH 1), and in the grade corresponding to the ABGD PSH 6, the maximum genetic distance was $2.8 \%$. The clusters 
$\mathrm{B}, \mathrm{C}$ and D proposed based on the shell morphology (marked on the figure 1) each corresponded to a ABGD-based PSH (PSHs 2, 6 and 7 respectively). Clusters B and D corresponded to clades and the cluster $\mathrm{C}$ to the grade 6 . The specimens of PSHs 6 and 7 together formed a wellsupported clade, and these two PSHs appear to be sympatric in New Ireland. In contrast, specimens of the morphological cluster A fell into four separate ABGD-based PSHs, 1, 3, 4, and 5, which did not form a clade. PSH 1 from the western Indian Ocean showed supported affinity to the sympatric, but morphologically distinctive PSH 2, and PSH 3 was recovered as a sister group of the resulting West-Indian Ocean clade (PSHs 1 + 2). The remaining allopatric PSHs 4 and 5 were sister-groups, and the clade comprising the PSHs 4 and 5 was the sister-group to the clade of the PSHs 1, 2, and 3. Even Indo-West Pacific PSHs, referable to the morphological cluster A did not form a clade. The phylogenetic pattern among the PSHs 3, 4 and 5 suggested that they correspond to either two or three species. Re-examination of shell morphology in the specimens of these three PSHs, as well, as of PSH 1, revealed subtle, but stable differences, among all four COI-determined PSHs, mainly in the position and morphology of the sculptural elements on the spire whorls, in sculpture of the shell base, and in presence or lack of a coloured band on the shell base (Table 2). In turn, the sequenced specimens of the PSH 6 varied notably in colour pattern and prominence of the spines on the shoulder, but the observed morphological variation showed no correlation with the inferred phylogenetic relationships among specimens.

<insert Table 2>

Based on i) the reciprocal monophyly of the ABGD PSHs 1-5 and 7, ii) published data on the variance of intertaspecific genetic distances in the Conoidea (Puillandre et al. 2009; Fedosov \& Puillandre 2012; Fedosov et al. 2017), and iii) described phylogenetic and biogeographic pattern and morphological differences among PSHs, we consider each COI-based PSH to correspond to an SSH (to be referred to as SSHs 1 - 7). The specimens of SSH 6, do not form a clade, and some specimens from the same locality (such as the MNHN-IM-2013-86072 and MNHN-IM2013-86073) show some degree of divergence from one another. Nevertheless, here we conservatively consider this assemblage of specimens as a single species, leaving drawing accurate boundaries within this group to further studies with more powerful and sensitive tools (such as RAD-seq - Abdelkrim et al. 2018).

<insert Figure 2>

The name Clavus rugizonatus is applied to SSH 7 in agreement with our initial identification and as supported by the comparison of the sequenced specimens with the type of $C$. rugizonatus. SSH 6 is here considered to correspond to C. canalicularis. 
The members of SSH 1, although immature, had strong nodules slightly lower than the midheight of late teleoconch whorls, and the shell periphery bearing wide, but distinct axial folds originating at the shoulder, sometimes with secondary weaker folds in interspaces. This sculpture gives the periphery of the last whorl a 'battered' appearance. The specimens of the SSH 3 have smooth periphery of the last adult whorl, while the position of the shoulder is also close to the whorl's mid-height. Finally, SSH 5 specimens had a very wide subsutural ramp, resulting in the shoulder being shifted abapically, and bordered by the lower suture. The periphery of the last whorl in these specimens is sculptured by rounded, spirally arranged granules, and resembles specimens of Clavus rugizonatus. The specimen NHMUK 1966492, illustrated by Kilburn and co-authors (2014) as possible holotype of Clavus exasperatus with its shoulder situated close to the mid-height of late whorls, and the shell periphery bearing notable wide folds with secondary ribs in intersections, is certainly closest to the specimens of the SSH 1. Thus, we pinpoint the name $C$. exasperatus to this Indian Ocean SSH. Three more described species show resemblance to and may be considered as part of the $C$. canalicularis complex: $C$. sikesi (Preston, 1908), $C$. groschi Kilburn 1988, and C. devexistriatus Kilburn, Fedosov \& Kantor, 2014. However, they do not show sufficient resemblance to be considered as applying to any of the sequenced species. Pleurotoma exigua Hombron \& Jacquinot, 1848 (a name previously considered synonymous to Clavus exasperatus - Kilburn et al. 2014), with type locality off Queensland (Australia), might prove to apply to the SSH 3, SSH 4 or SSH5. However, the type of this species is lost (Wells 1991; Kilburn et al. 2014), and the original illustration of Hombron \& Jacquinot (1848: plate 25, figures 21,22 ) is not sufficient for the unambiguous allocation of the name to one of the inferred SSHs. Restoring a name that, may have priority over newly proposed names, but which cannot be unequivocally attributed to a species is in our opinion, an unjustified taxonomic act. Describing a new species is more appropriate in such a situation (Bouchet \& Strong, 2010; Puillandre et al. 2017). Based on the combination of molecular and morphological characters, we consider our SSHs 2 - 5 to correspond to four as yet undescribed species; below we provide descriptions of these four new species that we name after four prominent rock guitarists. The distributions provided in the text and Figure 2 are based on the records of sequenced specimens, unless specified otherwise. Clavus devexistriatus is not treated below as there have been no additional specimens available for study after the monograph of Kilburn and coworkers (2014). The specimens photographed in standard position, with shell longitudinal axis parallel to the surface, and shell aperture facing the spectator); measurements correspond to shell height rounded to tenths of millimetres. 


\section{Systematics}

\section{Order Neogastropoda Wenz, 1938}

Superfamily Conoidea Fleming, 1822

Family Drilliidae Olsson, 1964

Genus Clavus Montfort, 1810

Type species (OD): Clavus flammulatus Montfort, 1810.

See Powell (1966: 70) and Tucker (2004) for synonymy.

\section{Clavus canalicularis (Röding, 1798)}

(SSH 6) Figs 3A - G.

Synonymy

Strombus canalicularis Röding, 1798: 100 (as Strombus lividus Gmelin, 1791, and Chemnitz 1786: pl. 136, figs 1269-1270). Type locality: not provided.

Clavatula auriculifera Lamarck, 1816: p. 9, pl. 439, figs 10a-b. Type locality not provided.

Clavus canicularis [sic]; Powell 1966: text-fig. D84 (radula), pl. 10, fig. 18; Cernohorsky 1972: 185, pl. 53, fig. 13; Higo et al. 1999: 298.

Clavus canalicularis; Wells 1991: 7, pl. 2, figs 7-8, 9 (syntype); Wilson 1994: 184, pl. 40, fig. 1; Kilburn et al., 2014: 6, Fig. 1.

Clavus (Tylotia) canicularis; Hasegawa et al. 2000: 621, pl. 309, fig, 13.

Drillia (Clavus) auriculifera; Bouge \& Dautzenberg 1914: 135.

Tylotia auriculifera; Habe 1970: 120, pl. 38, fig. 15.

\section{Type material}

Strombus canalicularis: types not traced, locality not given. Clavatula auriculifera: two syntypes MHNG 1097/48/1-2 (Kilburn et al., 2014), locality unknown.

\section{Type locality}

Unknown

\section{Material sequenced}

MNHN-IM-2013-54347, 1 lv, KAVIENG 2014, St. KR102, 2³8'S; 150²7'E, 3-18 m, 28.3 mm; MNHN-IM-2009-19204, 1 lv, PANGLAO 2004, St. S12, 9²9'N; 12356'E, 6-8 m, 16.5 mm; 
MNHN-IM-2007-42345, $1 \mathrm{lv}$, locality data same as previous, $18.8 \mathrm{~mm}$; MNHN-IM-2007-42351, locality data same as previous, $15.2 \mathrm{~mm}$; MNHN-IM-2007-42352, $1 \mathrm{lv}$, locality data same as previous, $12.2 \mathrm{~mm}$; MNHN-IM-2007-42353, 1 lv, locality data same as previous, $15.1 \mathrm{~mm}$; MNHN-IM-2007-17858, 1 lv, locality data same as previous, $12.1 \mathrm{~mm}$; MNHN-IM-200742547(Figure 3B), 1 lv, SANTO 2006, St. DS10, 15³6'S; 167¹0'E, 6-24 m, 23.4 mm; MNHNIM-2013-80899, 1 lv, KOUMAC 2.1, St. KR625, 20³5'S; 164¹6'E, 8m, 23.2 mm; MNHN-IM2013-85102, 1 lv, KOUMAC 2.1, St. KR625, 20³5'S; 164²16'E, 8m, 16.6 mm; MNHN-IM2013-84499, 1 lv, KOUMAC 2.1, St. KR634, 2046'S; 164²19'E, 18m, $18.1 \mathrm{~mm}$ (figure $3 \mathrm{~A}$ ); MNHN-IM-2013-84846, 1 lv, KOUMAC 2.1, St. KR218, 20³6'S; 164'10'E, 11m, 17.1 mm; $\mathrm{CvCn} 1$, same locality as previous; $\mathrm{CvCn} 2$, same locality as previous; MNHN-IM-2013-86071, same locality as previous; MNHN-IM-2013-86072, same locality as previous; MNHN-IM-201386073, same locality as previous; MNHN-IM-2013-86074, same locality as previous; MNHNIM-2013-86075, same locality as previous (figure 3 C); MNHN-IM-2013-86076, same locality as previous.

\section{Other material examined}

IM-2013-55814, 1 lv, KAVIENG 2014, St KR192, 2³6'S; 15047'E, 7-18 m. Also see Kilburn et al. (2014).

\section{Diagnosis}

[adapted from Kilburn et al. 2014] Shell robust, biconic-claviform or broadly claviform with orthoconoid spire. Protoconch narrowly domed, of about 1.5 smooth whorls. Teleoconch of 6 to 7.5 strongly shouldered whorls, subsutural region concave, suture narrowly undercutting succeeding whorl, irregularly undulating. Early spire whorls sculptured by wide axial folds forming nodules or sharp projections on peripheries about whorl's mid-height. Late 3-4 whorls with strong squamiform, spines directed outwardly on peripheries, especially long on penultimate and last whorls. Shell base smooth or with single row of low, rounded nodules. Spiral sculpture indistinct on spire whorls; last whorl with rugose, sometimes gemmate cords; fasciole with 6-7 low rounded declivous cords. Axial sculpture of dense growth lines. Aperture wide, anal sinus openly U-shaped, directed adapically, or V-shaped in immature shells. Parietal nodule large, stromboid notch distinct. Inner aperture lip heavily calloused. White, cream or uniformly pale, usually with a broad deep orange-brown zone at mid-last whorl, or uniformly light-brown.

\section{Distribution}


Philippines, Papua New Guinea, Vanuatu, New Caledonia, Japan (based on the specimen illustrated by Hasegawa et al.: 2000).

$<$ insert Figure 3>

\section{Remarks}

The species shows wide variation in coloration, shell proportions and prominence of nodules / spines. It can be differentiated from other allied species by its squamiform sculpture elements, (which are diagnostic per se if they form spines), by shoulder situated at mid-height of the whorl, by lack of sculpture, or by prevalence of spiral elements on the shell base. Morphologically $C$. canalicularis is most similar to C. rugizonatus (Figures 3H, I). The two species, however, are sympatric in Papua New Guinea and New Caledonia, and can be differentiated by the lack of spirally-aligned nodules on the shell base of the former species. Another clearly closely related species, unfortunately, lacking from our phylogenetic dataset (and therefore not provided with a separate entry herein) is Clavus devexistriatus Kilburn, Fedosov \& Kantor, 2014. Unlike $C$. canalicularis, the latter species possesses widely set striae, well pronounced throughout the height of last whorl (Figure 3H). Furthermore, unlike all other species considered herein, $C$. devexistriatus displays a colour pattern with brown adapical portion of whorls, and cream-white or pale shell base.

\section{Clavus rugizonatus Hervier 1896}

Figs 3I, J

Synonymy

Clavus rugizonatus Hervier, 1896a: 142; Hervier 1896b: 53, Pl. 1, Fig. 3; Kilburn et al. 2014: 10, Figs 3A - B (holotype), D, E - F.

Drillia (Clavus) rugizonata; Bouge \& Dautzenberg 1914: 142.

\section{Type material}

Kilburn et al. (2014) cite 15 original syntypes, (4 syntypes in MNHN IM-2000-3203, IM-20003204 (Figure 3I); doubtful syntypes in IRSNB and NMSA).

\section{Type locality}

Lifou, New Caledonia.

\section{Material sequenced}

MNHN-IM-2013-46868, 1 lv, KAVIENG 2014, St. KR04, 2³5'S, 16.3 mm; 15046'E, 6-22 m; MNHN-IM-2013-47244, 1 lv, KAVIENG 2014, St. KS03, 2³4'S; 15047'E, 8-10 m, 18.6 mm; MNHN-IM-2013-47756, 1 lv, KAVIENG 2014, St. KS11, 2³3'S; 15048'E, 7 m; MNHN-IM- 
2013-47761, 1 lv, KAVIENG 2014, St. KB08, 2³3'S; 15048'E, 13 m, 17.8 mm (Figure 3J); MNHN-IM-2013-50759, 1 lv, KAVIENG 2014, St. KS21, 2³5'S; 15046'E, 4 m, 15.8 mm; MNHN-IM-2013-51246, 1 lv, KAVIENG 2014, St. KR54, 242'S; 150³9'E, 7-10 m, 16.9 mm; MNHN-IM-2013-53414, 1 lv, KAVIENG 2014, St. KZ02, 2³7'S; 15044'E, 9 m, 19.0 mm; MNHN-IM-2013-53452, 1 lv, KAVIENG 2014, St. KR70, 240'S; 150³9'E, 9-11 m, shell crushed; MNHN-IM-2013-53453, 1 lv, locality data same as previous, $19.5 \mathrm{~mm}$; MNHN-IM2013-53454, $1 \mathrm{lv}$, locality data same as previous, shell crushed; MNHN-IM-2013-53455, locality data same as previous, $17 \mathrm{~mm}$; MNHN-IM-2013-53456, $1 \mathrm{lv}$, locality data same as previous, shell crushed; MNHN-IM-2013-54373, 1 lv, KAVIENG 2014, St. KB46, 2³5'S; 150³3'E, 8 m, $18.8 \mathrm{~mm}$.

\section{Diagnosis}

[adapted from Kilburn et al. 2014] Shell broadly biconic-claviform with sharp, orthoconoid spire (breadth/length 0.42-0.52) and relatively wide aperture (aperture/total length 0.35-0.40). Suture channeled, irregularly undulating. Sculpture of widely set prominent squamiform nodes situated at mid-height of spire whorls. Shell base evenly truncate, with 3-4 spirally aligned rows of minute nodules, with strong fasciole and concavely indented termination of siphonal canal. Outer lip weakly convex in side view, serrated, anal sinus openly U-shaped, directed adapically, parietal nodule large, stromboid notch distinct but shallow; columella with wide, rounded callus. Shell chalky-white with orange or light-brown band on shell periphery.

\section{Distribution}

New Caledonia, New Ireland.

\section{Remarks}

The species can be differentiated from its congeners in the Clavus canalicularis complex by the combination of strongly-pronounced nodes situated at whorls mid-height, and the presence of distinct yellow to light-brown band and 3-4 rows of spirally aligned nodules on the shell periphery.

\section{Clavus exasperatus (Reeve, 1843)}

Figs 4A, B

Synonymy

Pleurotoma exasperata Reeve, 1843: Pl. 2, sp. 8. 
Clavus exasperatus Higo et al. 2001: 100, Fig. G3542 (holotype); Kilburn et al., 2014: 12, Figs 4A - B (holotype).

\section{Type material}

P. exasperata: probable holotype NHMUK 1966462 (Kilburn et al. 2014), type locality unknown. Kilburn et al. (2014) also cite a type of Pleurotoma exigua Hombron \& Jacquinot 1848 , as representing C. exasperatus, however, in the light of our results most likely it is not a synonym of Clavus exasperatus (see remarks section).

\section{Type locality}

\section{Unknown.}

\section{Material sequenced}

MNHN-IM-2009-14866, 1 lv, ATIMO VATAE, St. TS02, 25ํ'1'S; 470'E, 18 m, $23.1 \mathrm{~mm}$

(Figure 4B); MNHN-IM-2009-26514, 1 lv, INHACA 2011, St. MS02, 26º' 'S; 3258'E, 17-19 m, $17.3 \mathrm{~mm}$.

\section{Diagnosis}

Shell thick, broadly claviform with sharp, initially coeloconoid spire, and fasciole strong, with distinct false umbilicus. First 2-3 teleoconch whorls rather flat-sided, with very low suture-to-suture axial ribs; thereafter, axials progressively weaker subsuturally and more tumid basally. Later whorls strongly shouldered, with strongly concave adapical region. Shoulder at about whorl's mid-height, marked with prominent nodules, rounded, or sometimes weakly squamiform on late whorls. Base of nodules rapidly evanescing above last suture. Microsculpture of dense irregular collabral growth lines, well pronounced on adapical regions; and very fine spiral striae on whorls base. Shell base with wide, irregular spiral folds, giving it somewhat crumbled appearance. Aperture oblong-ovate, outer lip slightly alate, base wide, oblique, shallowly indented. Outer lip slightly prosocline, strongly serrated, stromboid notch very deep, anal sinus U-shaped, directed slightly adapically, with distinct parietal pad. Background colour yellowishwhite, with broad, orange or light-brown band around middle of last whorl; columella and lip white, interior of aperture yellowish.

\section{Distribution}

Mozambique, Madagascar.

<insert Figure 4>

\section{Remarks}


Clavus exasperatus as circumscribed herein can be differentiated from its congeners in the $C$. canalicularis complex by the combination of nodules situated about mid-height of late teleoconch whorls, presence of wide rounded folds, and a brown spiral band on shell periphery. Similar features are displayed by $C$. groschi (Figure 4F), but the latter species possesses oblique, axially elongated nodules with rather sharp crests, whereas Clavus exasperatus has rounded nodules, typically squamiform at late whorls.

The results of our phylogenetic analysis reject the previously accepted concept of widely distributed and variable Clavus exasperatus, which has long been established in the literature (Tucker 2004; Kilburn et al. 2014). Our results suggest that Clavus exasperatus is actually a western Indian Ocean species, although its eastern range limit is uncertain due to the paucity of sampling efforts along the African Coast and in the central Indian Ocean. Nevertheless, based on this contraction of the C. exasperatus distribution range, previous records of this species from the Indo-West Pacific need to be critically reevaluated. We are unable to unequivocally place the specimen figured by Hasegawa et al. (2000: plate 309, figure 8), into one of the species recognized herein, due to the poor condition of the shell. The specimens illustrated in Philippine Marine Molluscs Vol. 2 (Sysoev 2008) certainly represent $C$. davidgilmouri n. sp. - see synonymy of the latter species. Finally, it is most likely, that Pleurotoma exigua Hombron \& Jacquinot, 1848 from Torres Strait off Queensland is not a synonym of C. exasperatus as circumscribed herein, but actually is a different species, possibly one of the species dealt with in the present paper. Nevertheless, as ascertaining the identity of Pleurotoma exigua is virtually impossible, due to the loss of the type specimen, we are unable to assign this name, and judge that describing a new species to be a more justifiable option.

\section{Clavus brianmayi n. sp.}

Figs 4C - E

Clavus canalicularis Kilburn, Fedosov \& Kantor 2014 (in part): Kilburn et al. (2014), Figs 1I, J.

Clavus exasperatus Kilburn, Fedosov \& Kantor 2014 (in part): Kilburn et al. (2014), Figs 4E, F.

Zoobank registration: urn:1sid:zoobank.org:act:D664B2E0-C964-4D58-849A-43914D3CDEC2

\section{Type material}

Holotype: MNHN IM-2013-85593, KOUMAC 2.1 St. KR643, 2045'S; 164¹6'E, 7m, 27.8 mm (figures $4 \mathrm{C}, \mathrm{D}$ ). 
Paratypes: MNHN IM-2013-85594, lv, 27.2 mm, MNHN IM-2013-85595, lv 27.3 mm, same locality as holotype [all three dissected for venom gland transcriptome; shells broken].

\section{Sequenced material}

Holotype and paratypes.

\section{Other material examined}

Loyalty Islands, Lifou, LIFOU 2000, St. 1422, 2047.1'S; 16707.4' E, 4 m, 27.7 mm (figure 4 E); LAGON St. DW545, Grand Récif Sud, 2252'S; 166 50'E, 37 m, 30.8 mm (Kilburn et al. 2014).

\section{Description}

Shell medium-sized, chalky-white, claviform with orthoconoid spire and massive base.

Protoconch not examined as the apex is strongly corroded. Teleoconch of about 9 whorls. Suture deeply canaliculate. Three early spire whorls flattened in outline, with widely set rounded folds pronounced throughout whorl height. Later whorls sculptured with strong, prominent, widely interspaced nodules, shifted towards lower suture, demarcating very wide and distinctly concave subsutural ramp. Nodules on penultimate and last whorl clearly squamiform, counting 12 and 17 respectively. Axial sculpture of fine collabral growth lines well pronounced on late teleoconch whorls. Subsutural ramp on last whorl somewhat depressed; shell periphery gently convex, smooth, gradually sloping to robust shell base, also with no demarcation between shell base and siphonal canal.

Aperture ovate, outer lip simple, thin, with distinct stromboid notch and wide opening of siphonal canal. Anal sinus moderately deep, rounded. Inner lip smooth, with well-developed callus. Protoconch and early teleoconch whorls light brown, late - chalky-white; outer and inner lips white, and inside of aperture light brown.

\section{Distribution}

New Caledonia.

\section{Etymology}

The species name honours Brian Harold May CBE, British astrophysicist and guitarist, member of the band Queen. 


\section{Remarks}

The combination of smooth periphery of the last whorl, nodules shifted towards lower aperture on spire whorls and the lack of any colouration on late teleoconch whorls easily distinguishes Clavus brianmayi $\mathrm{n}$. sp. from the other species of the $C$. canalicularis complex. The stout shell of Clavus brianmayi n. sp. also resembles C. boucheti Kilburn, Fedosov \& Kantor, 2014, but the latter species has rounded (not squamiform) axial elements, and a light-orange spiral band on the periphery of last whorl.

\section{Clavus davidgilmouri n. sp.}

Figs 4G - I

Clavus exasperatus Sysoev 2008. Pl. 673, Figs 4, 5

Clavus rugizonatus Kilburn, Fedosov \& Kantor 2014. Fig. 3C.

Zoobank registration: urn:1sid:zoobank.org:act:57419068-42C6-410B-BEFA-2BD2A1D413D8

\section{Type material}

Holotype: MNHN-IM-2013-86068, lv, off Cow-Oy, N. Olango Is, Philippines, 15-25 m, 25.4 mm (Figures 4G, H).

Paratypes: P1. MNHN-IM-2013-86069, lv, same locality as holotype, $25.2 \mathrm{~mm}$ (Figure 4I); P2. MNHN-IM-2013-86070, lv, same locality as holotype, $25.3 \mathrm{~mm}$.

\section{Sequenced material}

Holotype and all paratypes; MNHN-IM-2009-19172, 1 lv, PANGLAO 2004, St. B9, 9³3'N; $123^{\circ} 44^{\prime} \mathrm{E}, 8-10 \mathrm{~m}, 17.9 \mathrm{~mm}$; MNHN-IM-2007-42341 same locality data as previous, $16.4 \mathrm{~mm}$.

\section{Description}

Shell medium-sized, claviform, with rather low spire. Protoconch not examined as apex strongly eroded by calcareous algae. Suture deeply canaliculate. Teleoconch of $5.5-6$ whorls, early teleoconch whorls with overall flattened outline, nuanced by rather rounded base due to fine nodules bordered by lower suture. Nodules becoming sharper and more pronounced on penultimate and last whorls, starting about whorl's mid-height and continuing abapically as wide rounded slightly opisthocline folds. Nodules on last whorl finely squamiform. Subsutural ramp 
steep, clearly delineated from the distinctly elevated succeeding portion of whorl. Base of penultimate and last whorl with coarse but low, irregularly interrupted spiral cords.

Microsculpture of very weak growth lines, and of very fine dense grooves on periphery of last adult whorl. Shell base smooth, forming a short, thick, widely open siphonal canal with distinct fasciole.

Aperture wide, ovate; outer aperture lip wavy, with small stromboid notch in its anterior part. Anal sinus moderately deep, U-shaped, constricted adapically by a strong callous pad. Inside of aperture white, inner lip with well-developed callus.

Shell chalky-white with distinct dark band on lower periphery of last adult whorl that is sometimes seen on penultimate whorl.

\section{Distribution}

Central Visayas, the Philippines.

\section{Etymology}

The species epithet honours David Jon Gilmour CBE, British guitarist, member of the band Pink Floyd.

\section{Remarks}

Clavus davidgilmouri n. sp. can be distinguished from the other species of the analysed complex by the periphery of the last whorl, sculptured with spirally aligned nodules merged into undulating cords, and bearing a dark spiral band, in combination with a very wide subsutural ramp giving the spire whorls a flat to somewhat concave outline (Table 2). Although the spire of this species is often encrusted by calcareous algae, the characteristically sculptured periphery of the last adult whorl is always available for examination.

\section{Clavus andreolbrichi n. sp.}

\section{Figs 4J - L}

Clavus exasperatus Kilburn, Fedosov \& Kantor 2014: Figs 4C, D, G. 
Holotype: MNHN-IM-2013-54871, 1 lv, KAVIENG 2014, St. KZ02, 2³7'S; 15044'E, 9 m, 26 mm (Figures 4J, K).

Paratypes: P1. MNHN IM-2007-42576, 1 lv, SANTO 2006, St. FR30, 15²7'S; 167¹5'E, 0-45 m, 25.73 mm (Figure 4L); P2. MNHN-IM-2007-42553, 1 lv, SANTO 2006, St. NR08, 15³6'S; 1677'E, 11 m, 18.8 mm; P3. MNHN-IM-2007-42579, 1 lv, SANTO 2006, St. DR68, 15²3'S; 167²13'E, 7-27 m, 21.2 mm; P4. MNHN-IM-2009-16929, 1 lv, SANTO 2006, St. DR52, coordinates unknown, $23.8 \mathrm{~mm}$.

\section{Material sequenced}

Holotype and all paratypes.

\section{Description}

Shell medium-sized, claviform, with tall orthoconoid spire. Protoconch not examined as the apex strongly corroded. Teleoconch of about 8 whorls. Suture canaliculate. Whorls sculptured with strong, prominent, widely interspaced nodules, becoming sharper, notably more prominent and slightly extended axially on later whorls. Nodules situated just above lower suture on early teleoconch whorls, and slightly higher on penultimate and last whorls. 10 nodules on last whorl, 12 on penultimate whorl. Subsutural ramp very wide, steep adapically, and with clearly concave outline about mid-height of whorl. Micro-sculpture of dense, very fine collabral growth lines. Shell periphery smooth, evenly convex, siphonal canal very short and robust, widely open. Aperture ovate, with thin undulating outer lip, bearing distinct stromboid notch. Anal sinus moderately deep, U-shaped, constricted adapically by a strong callous pad. Inside of the aperture white, inner lip with well-developed callus.

Shell of uniform cream colour with vague tan spiral band on periphery.

\section{Distribution}

Papua New Guinea, Vanuatu, possibly, Loyalty Islands (based on the specimen Illustrated by Kilburn et al. 2014: Figure 4G).

\section{Etymology}

The species honours André Olbrich, German guitarist, member of the band Blind Guardian.

\section{Remarks}


Drillia sikesi Preston, 1908 (holotype - Figure 4M), is conchologically close to Clavus andreolbrichi $\mathrm{n}$. sp., but has more prominent and widely set knobs, which are located higher in relation to the whorls lower sutures, and are extended notably on the last whorl. Clavus andreolbrichi $\mathrm{n}$. sp. can be distinguished from other species of the C. canalicularis complex by the combination of smooth and lightly colored shell periphery, and wide subsutural ramp, with knobs marking position of the shoulder shifted towards lower suture (Table 2). C. davidgilmouri n. sp., although is morphologically close to Clavus andreolbrichi n. sp., possesses a very rough shell periphery with a darker band. Some specimens of $C$. canalicularis that demonstrate similar coloration and also weakly sculptured shell periphery (for example, MNHN-IM-2007-42547), can be differentiated from $C$. andreolbrichi $\mathrm{n}$. sp. by a narrower subsutural ramp, and by protruded, distinctly squamiform tubercles.

\section{Clavus kirkhammetti n. sp.}

Figs $5 \mathrm{~A}-\mathrm{C}$

Zoobank registration urn:1sid:zoobank.org:act:B70B5543-6C9A-413B-96B8-01C3F8B8F27F

\section{Type material}

Holotype: MNHN-IM-2009-14898, 1 lv, ATIMO VATAE, St. BP22, 25²3'27"S; 4451'39"E, 20-22 m, 20.3 mm (Figures 5A, B).

Paratypes: P1. MNHN-IM-2009-14776, 1 lv, ATIMO VATAE, St. BV05, 2527'S; 4456'E, 1418 m, 23.3 mm (Figure 5C); P2. MNHN-IM-2009-14800, 1 lv, ATIMO VATAE, St. CP3603, 255' S; 444ㄱ'E, 62-63 m, 28.6 mm; P3 MNHN-IM-2009-14856, 1 lv, ATIMO VATAE, St. BP21, 252'' S; 4451'E, 20-23 m, 20.7 mm; P4 MNHN-IM-2009-14865, 1 lv, ATIMO VATAE, St. BS04, 2527'S; 445'ㄹ, 14-18 m, 12.5 mm; P5 MNHN-IM-2009-14930, 1 lv, ATIMO VATAE, St. CP3624, 2538'S; 4557'E, 63 m, 35.1 mm.

\section{Material sequenced}

Holotype and all paratypes.

<insert Figure 5>

\section{Description}

Shell small to medium-sized, claviform, with high orthoconoid spire and rather gentle sculpture. Protoconch paucispiral, of about 1.5-1.75 white smooth whorls. Teleoconch of about 8 whorls; 
suture deeply impressed but not canaliculate. Early teleoconch whorls with blunt angulation at about mid-height; later - with steep slightly concave subsutural ramp changed by rounded shoulder at about mid-height of whorl. Sculpture of regular, rounded axial folds (14 on last whorl, 12 on penultimate whorl), weaker pronounced on subsutural ramp, and stronger on shoulder and on whorl periphery. On last adult whorl subsutural ramp separated from lower portion of whorl by a distinct, although rather wide groove. Miscrosculpture of very fine, vanishing collabral growth lines, intersected by dense also very fine grooves in the interspaces between axials. Shell base with somewhat truncated appearance; siphonal canal short and robust, widely open, with well-developed fasciole.

Aperture ovate; outer lip with distinct stromboid notch in its anterior part, irregularly denticulate within. Anal sinus rather deep, U-shaped, constricted by a callous pad at posterior apertural corner. Inner lip with well-developed pale callus. Shell uniformly tan to sometimes lighter subsutural ramp, shell base and crests of axial folds, darker whorls' periphery, and interspaces between axials light brown.

\section{Distribution}

Off South Madagascar, shallow subtidal depths.

\section{Etymology}

The species name honours Kirk Lee Hammett, American guitarist, member of the band Metallica.

\section{Remarks}

Clavus kirkhammetti n. sp., although showing close affinity to C. exasperatus, is different from the latter, as well, as from other species of the analysed complex, in having a more elongated shell with lower and more numerous nodules at shoulder extended into rounded folds, and by its comparatively much shallower suture. Besides, the species can be readily identified by its colouration, lacking a contrasting band on the shell periphery, and sometimes showing an almost uniformly tan shell.

It should be noted that conchologically, Clavus kirkhammetti n. sp. cannot be attributed to the $C$. canalicularis species complex, and the position of this species in the tree (as a sister to $C$. exasperatus) rejects the monophyly of the Clavus canalicularis complex. Further studies with broader taxon sampling are needed to shed light on the relationships of the forms analyzed herein 
within Clavus, as well, as to establish limits between the genera Clavus, Drillia Gray, 1838 and Tylotiella Habe, 1958. 


\section{Discussion}

Our analysis, although restricted taxonomically, represents the first integrative taxonomy study on the family Drilliidae. Re-evaluation of species delimitation within the Clavus canalicularis complex once again demonstrates how the conservative approach that was widely followed by taxonomists of the Conoidea in the past lumped morphologically distinguishable forms, which once assigned to a nominative species, remained unnoticed until they were subject to DNA sequencing studies. Our analysis doubled the number of known species in this group of rather large drilliids from shallow waters, i.e. the fraction of molluscan diversity that is most easily collectable and thus can be expected to be best studied taxonomically. If these results are extrapolated to the entire family, we can speculate that shelves of natural history museums of the world hold at least as many new species of Drilliidae as are described to date, although this speculative estimate needs be corrected to take into account the probably better knowledge of Atlantic Drilliidae (following the recent revision by Fallon 2016). On the other hand, it also likely underestimates the number of species awaiting description in the deep water (Bouchet $e t$ al. 2009), such as those in the genus Splendrillia. To systematically describe this diversity, the taxonomy of the family should be revisited with the adequate methodology to propose robust hypotheses for included taxa. We hope that the present work will inspire further studies of the family Drilliidae to improve the state of its taxonomy and to guide future investigations of drilliid venoms.

\section{Acknowledgments}

The material in this paper originates from several shore-based expeditions conducted by MNHN and Pro-Natura International (PNI) as part of the Our Planet Reviewed programme (SANTO 2006, ATIMO VATAE, INHACA 2011, KAVIENG 2014, KOUMAC 2.1; principal investigator P. Bouchet) Scientific partners included the University of Papua New Guinea (UPNG); National Fisheries College, Kavieng, Papua New Guinea; Institut d'Halieutique et Sciences Marines (IH.SM), Université de Tuléar, Madagascar; Universidade Eduardo Mondlane, Maputo; the Madagascar bureau of the Wildlife Conservation Society (WCS); and the Conservatoire d'Espaces Naturels (CEN) de Nouvelle-Calédonie. Funders and sponsors included the Total Foundation, Prince Albert II of Monaco Foundation, Stavros Niarchos Foundation, Richard Lounsbery Foundation, Vinci Entrepose Contracting, Fondation EDF, European Regional Development Fund (ERDF), French Ministry of Foreign Affairs, Fonds Pacifique, the Government of New Caledonia, the Province Nord of New Caledonia and the Agence Française de la Biodiversité (AFB). Additional fieldwork included PANGLAO 2004, a joint project of MNHN and University of San Carlos, Cebu City. All expeditions operated under the regulations 
then in force in the countries in question and satisfy the conditions set by the Nagoya Protocol for access to genetic resources.

We are grateful to Igor Muratov (NMSA) for providing photos of the type of Clavus groschi, the photo of the type of Drillia sikesi was accessed from the unpublished archive of images of Richard Neil (Dick) Kilburn. The authors thank Virginie Héros, Barbara Buge, Philippe Maestrati and Julien Brisset (MNHN) for their help in curating the vouchers and for their edits on the text of the manuscript. Comments of two anonymous reviewers helped to improve the quality of the manuscript. This work was supported by the Service de Systématique Moléculaire (UMS 2700 CNRS MNHN), and by Russian Science Foundation (grant N 19-74-10020 to AF).

\section{References}

Abdelkrim, J., Aznar-Cormano, L., Fedosov, A., Kantor, Y., Lozouet, P., Phuong, M., Zaharias \& P., Puillandre, N. (2018). Exon-capture based phylogeny and diversification of the venomous gastropods (Neogastropoda, Conoidea). Molecular Biology and Evolution 35, $2355-2374$.

Abdelkrim, J., Aznar-Cormano, L., Buge, B., Fedosov, A., Kantor, Y., Zaharias \& P., Puillandre N. (2018). Delimiting species of marine gastropods (Turridae, Conoidea) using RADsequencing in an integrative taxonomy framework. Molecular Ecology 27, 4591-4611.

Bouchet, P., Kantor, Y.I., Sysoev, A.V. \& Puillandre, N. (2011). A new operational classification of the Conoidea (Gastropoda). Journal of Molluscan Studies 77, 273-308.

Bouchet, P., Lozouet, P. \& Sysoev, A.V. (2009). An inordinate fondness for turrids. Deep-Sea research II 56, 1724-1731.

Bouchet, P. \& Strong, E.E. (2010). Historical name-bearing types in marine molluscs: an impediment to biodiversity studies? In: Polaszek, A., Systema Naturae 250 - The Linnaean Ark. Boca Raton, FL: CRC Press, pp.61-72.

Bouge, L.J., Dautzenberg, P. “1913” (1914). Les Pleurotomés de la Nouvelle Calédonie et de dépendancies. Journal de Conchyliologie 61, 123-214.

Cabang, A.B., Imperial, J.S., Gajewiak, J., Watkins, M., Corneli, P.S., Olivera, B.M. \& Concepcion, G.P. 2011. Characterization of a venom peptide from a crassispirid gastropod. Toxicon 58 (8), 672-680.

Cernohorsky, W. O. (1972) Marine Shells of the Pacific. Volume 2: Pacific Publications, Sydney, $411 \mathrm{pp}$. 
Chua, V.M., Gajewiak, J., Watkins, M., Espino, S.S., Ramiro, I.B.L., Omaga, C.A., Imperial, J.S., Carpio, L.P.D., Fedosov, A., Safavi-Hemami, H., Salvador-Reyes, L.A., Olivera, B.M. \& Concepcion, G.P. Purification and Characterization of the Pink-Floyd Drillipeptide, a Bioactive Venom Peptide from Clavus davidgilmouri (Family Drilliidae). Toxins submitted.

Fallon, P.J. (2016). Taxonomic review of tropical western Atlantic shallow water Drilliidae (Mollusca: Gastropoda: Conoidea) including descriptions of 100 new species. Zootaxa 4060, 1-363.

Fedosov, A. \& Puillandre, N. (2012). Phylogeny and taxonomy of the Kermia-Pseudodaphnella (Mollusca: Gastropoda: Raphitomidae) genus complex: a remarkable radiation via diversification of larval development. Systematics and Biodiversity 10, 447-477.

Fedosov, A.E., Stahlschmidt, P., Puillandre, N., Aznar-Cormano, L. \& Bouchet, P. (2017). Not all spotted cats are leopards: evidence for a Hemilienardia ocellata species complex (Gastropoda: Conoidea: Raphitomidae). European Journal of Taxonomy 268: 1-20.

Folmer, O., Black, M., Hoeh, W., Lutz, R. \& Vrijenhoek, R. (1994). DNA primers for amplification of mitochondrial cytochrome c oxidase subunit I from diverse metazoan invertebrates. Molecular Marine Biology and Biotechnology 3, 294-299.

Galindo, L.A., Puillandre, P., Strong, E.E. \& Bouchet, P. (2014). Using microwaves to prepare gastropods for DNA Barcoding. Molecular Ecology Resources 14, 700-705.

Gmelin, J.F. (1791) Caroli a Linné Systema naturae per regna tria naturae, Editio decima tertia, aucta reformata. Leipzig: G. E. Deer. Tome 1, pars 6 (Vermes), 3021-3910.

Habe, T. (1958) On the radulae of Japanese marine gastropods. Venus 20(1), 43-60.

Habe, T. (1970) Shells of the western Pacific in color. Volume 2. Hoikusha, Osaka: 233 pp.

Hasegawa, K., Okutani, T. \& Tsuchida, E. (2000) Family Turridae. In Okutani, T. (Ed.) Marine Mollusks in Japan. Tokai University Press, Tokyo, pp. 619-667.

Hervier, J. (1896a). Descriptions d'espèces nouvelles de l'Archipel Néo-Calédonien. Journal de Conchyliologie 43, 141-152, 236-240.

Hervier, J. (1896b) Descriptions d'espèces nouvelles de l'Archipel de la Nouvelle Calédonie. Journal de Conchyliologie 44, 51-95.

Higo, S., Callomon, P. \& Goto, Y. (1999) Catalogue and bibliography of the marine shellbearing Mollusca of Japan. Elle Scientific Publishers, Osaka, 749 pp.

Hombron, J.A. \& Jacquinot, M. (1854). Description de mollusques coquilles et zoophytes. In Rousseau, L. (Ed.) Voyage au Pôle Sud et dans l'Océanie sur les Corvettes l'Astrolabe et la Zélée; Exécuté par Ordre du Roi Pendant les Années 1837-1838-1839-1840, sous le Commandement de M. J. Dumont d'Urville, Capitaine de Vaisseau; Publié par Ordre du 
Gouvernement, sous la Direction Supérieure de M. Jacquinot, Capitaine de Vaisseau, Commandement de la Zélée. Zoologie Vol. 5. Gide et J. Baudry, Paris, pp. 1-132.

Huelsenbeck, J.P., Ronquist, F. \& Hall, B. (2001). MrBayes: bayesian inference of phylogeny. Bioinformatics 17, 754-755.

Kantor, Y., Stahlschmidt, P., Aznar-Cormano, L., Bouchet, P. \& Puillandre, N. (2017). Too familiar to be questioned? Revisiting the Crassispira cerithina species complex (Gastropoda: Conoidea: Pseudomelatomidae). Journal of Molluscan Studies 83, 43-55. Kilburn, R.N. (1988). Turridae (Mollusca: Gastropoda) of southern Africa and Mozambique. Part 4. Subfamily Drilliinae, Crassispirinae and Strictispirinae. Annals of the Natal Museum 29, 167-320.

Kilburn, R.N., Fedosov, A.E. \& Kantor, Y.I. (2014). The shallow-water New Caledonia Drilliidae of genus Clavus Montfort, 1810 (Mollusca: Gastropoda: Conoidea). Zootaxa 3818, 1-69.

Lamarck, J. B. P. A. (1816) Liste des objets représentés dans les planches de cette livaraison. Tableau encyclopédique et méthodique des trois règnes de la nature. Mollusques et polypes divers. Paris: Veuve Agasse, Imprimeur. livr. 83, 1-16 pp. and livr. 84, pls. 391488.

Lanfear, R., Frandsen, P. B., Wright, A. M., Senfeld, T. \& Calcott, B. (2017). PartitionFinder 2: new methods for selecting partitioned models of evolution for molecular and morphological phylogenetic analyses. Molecular biology and evolution 34, 772-773.

Lu, A., Watkins, M., Li, Q., Robinson, S.D., Concepcion, G.P., Yandell, M., Weng, Z., Olivera, B.M., Safavi-Hemami, H. \& Fedosov, A.E. (2020) Transcriptomic profiling reveals extraordinary diversity of venom peptides in unexplored predatory gastropods of the genus Clavus. Genome Biology and Evolution 12(5), 684-700.

McLean, J.H. (1971). A revised classification of the family Turridae with the proposal of new subfamilies, genera and subgenera from the eastern Pacific. The Veliger 14, 114-130.

Miller, M.A., Pfeiffer, W. \& Schwartz, T. (2010). Creating the CIPRES Science Gateway for inference of large phylogenetic trees". In: Gateway Computing Environments Workshop $(G C E))$, New Orleans, pp. 1-8.

Montfort, P.D. de (1810) Conchyliologie Systématique, et Classification Méthodique des Coquilles; Offrant leurs Figures, leur Arrangement Générique, leurs Descriptions Caractéristiques, leurs Noms; ainsi que leur Synonymie en Plusieurs Langues. 2. Coquilles Univalves, non Cloisonnées. F. Schoell, Paris, 676 pp. 
Nguyen, L.T., Schmidt, H.A., von Haeseler, A. \& Minh, B.Q. (2015). IQ-TREE: a fast and effective stochastic algorithm for estimating maximum-likelihood phylogenies. Molecular Biology and Evolution 32, 268-274

Olivera B.M., Fedosov A.E., Imperial J. \& Kantor Yu. I. (2017). Physiology of envenomation by conoidean gastropods. In: Saleuddin S., (Ed.) Physiology of Molluscs, Volume 1. New Jersey: Apple Academic Press. 153-188.

Olsson, A.A. (1964). Neogene Mollusks from Northwestern Ecuador. Paleontological Research Institution, Ithaca, New York, $256 \mathrm{pp}$.

Powell, A.W.B. (1966). The molluscan families Speightiidae and Turridae. Bulletin of the Auckland Institute and Museum 5, 1-184.

Preston, H.B. (1908). Descriptions of new species of land, marine and freshwater shells from the Andaman Islands. Records of the Indian Museum 2, 187-210.

Puillandre, N., Baylac, M., Boisselier, M.C., Cruaud, C. \& Samadi, S. (2009). An integrative approach to species delimitation in Benthomangelia (Mollusca: Conoidea). Biological Journal of the Linnean Society 96, 696-708.

Puillandre N, Fedosov AE, Zaharias P, Aznar-Cormano L. \& Kantor YI. (2017). A quest for the lost types of Lophiotoma (Gastropoda: Conoidea: Turridae): integrative taxonomy in a nomenclatural mess. Zoological Journal of the Linnean Society 181, 243-271.

Puillandre, N., Kantor, Y.I., Sysoev, A.V., Couloux, A., Meyer, C., Rawlings, T., Todd, J.A. \& Bouchet, P. (2011). The dragon tamed? A molecular phylogeny of the Conoidea (Gastropoda). Journal of Molluscan Studies 77, 259-272.

Puillandre, P., Lambert, A., Brouillet, S. \& Achaz, G. (2012). ABGD, Automatic Barcode Gap Discovery for primary species delimitation. Molecular Ecology 21, 1864-1877.

Rambaut, A., Suchard, M.A., Xie, D. \& Drummond, A.J. (2014). Tracer v1.4., http://beast.bio.ed.ac.uk/Tracer.

Reeve, L.A. (1843-46) Monograph of the Genus Pleurotoma. Conchologia Iconica, or Illustrations of the shells of molluscous animals. Reeve, London. Volume 1, pls 1-18 (1843); pl 19 (1844); pls 20-33 (1845); pls 34-40 + index and errata (1846).

Röding, P.F. (1798) Museum Boltenianum sive catalogus cimeliorum e tribus regnis naturae quae olim collegerat Joa. Fried Bolten, M.D. p.d., per XL. annus Proto physicus Hamburgensis. Pars Secunda continens conchylia sive testacea univalvia, bivalvia \& multivalvia. Johan Christi. Trapii, Hamburg. 199 pp.

Stamatakis, A. (2006). RAxML-VI-HPC: maximum likelihood-based phylogenetic analyses with thousands of taxa and mixed models. Bioinformatics 22, 2688-2690. 
Sysoev, A.V. (2008). Turridae. In Poppe, G. T. (Ed.) Philippine Marine Mollusks. Volume II. ConchBooks, Hackenheim, Germany, pp. 732-815.

Sysoev, A.V. \& Kantor, Y.l. (1989). Anatomy of molluscs of genus Splendrillia (Gastropoda: Toxoglossa: Turridae) with description of two new bathyal species of the genus from New Zealand. New Zealand Journal of Zoology 16, 205-214.

Tamura, K., Stecher, G., Peterson, D., Filipski, A. \& Kumar, S. (2013). MEGA6: Molecular Evolutionary Genetics Analysis Version 6.0. Molecular Biology and Evolution 30, 2725 2729.

Taylor, J.D., Kantor, Y.I. \& Sysoev, A.V. (1993). Foregut anatomy, feeding mechanisms and classification of the Conoidea (= Toxoglossa) (Gastropoda). Bulletin of the Natural History Museum of London (Zoology) 59, 125-170.

Tucker, J.K. (2004). Catalog of recent and fossil turrids (Mollusca: Gastropoda). Zootaxa 682, 11295.

Wells, F.E. (1991). A revision of the Recent Australian species of the turrid genera Clavus, Plagiostropha, and Tylotiella (Mollusca: Gastropoda). Journal of the Malacological Society of Australia 12, 1-33.

Wilson, B. R. (1994) Australian Marine Shells. Prosobranch Gastropods. part 2 (Neogastropods). Volume 2. Odyssey Publishing, Kallaroo, 408 pp.

Zaharias, P., Kantor, Yu.I., Fedosov, A.E., Criscione, F., Hallan, A., Kano, Y., Bardin, J. \& Puillandre, N. Just the once will not hurt: DNA suggests species lumping over two oceans in deep-sea snails. Zoological journal of the Linnean Society. In press. 


\section{Captions.}

Figure 1. RAxML tree of the Clavus canalicularis complex based on the barcode fragment of COI. Support values as RaxML bootstrap / IQtree bootstrap / Bayesian posterior probabilities. Locality data, composition of morphological clusters and COI-based PSHs as inferred by ABGD are shown on the right.

Figure 2. Map of Clavus canalicularis complex species distributions. Black characters - based on the records of sequenced specimens, grey characters - based on empty shells or literature. Empty triangles - Clavus canalicularis; empty squares $-C$. rugizonatus; empty circles $-C$. exasperatus; filled hexagon $-C$. devexistriatus; X-cross $-C$. sikies; filled triangles $-C$. davidgilmouri n. sp.; filled star -C. brianmayi n. sp.; filled rhomb -C. andreolbrichi n. sp.; filled circle - C. kirkhammetti n. sp.

Figure 3. Species of C. canalicularis complex. A - G. Clavus canalicularis. A. MNHN-IM2013-84499, KOUMAC 2.1, St. KR634, 2046'S; 164²19'E, 18m, 18.1 mm; B. MNHN-IM2007-42547, SANTO 2006, St. DS10, 15³6'S; 167¹0'E, 6-24 m, 23.4 mm; C. MNHN-IM2013-86075, Philippines, off N. Olango Is, 15-25 m; D, E. New Caledonia, Nouméa Sector, St. 1347, 31.2 mm; F. MNHN-IM-2013-86074, Philippines, off N. Olango Is, 15-25 m; G. New Caledonia, Grand Récif Sud, LAGON St. DW545, 2252'S; 16650'E, 37 m, 30.8 mm; H, I. Clavus rugizonatus. H. Clavus devexistriatus, holotype, MNHN-IM-2000-26936, Chesterfield Plateau, CORAIL 2, St. DW67, 19¹4.9'S, 158³6.9'E, 66 m, 15.7 mm; I. Possible syntype of Clavus rugizonatus MNHN-IM-2000-3204, Loyalty Islands, Lifou, 19.3 mm; J. MNHN-IM2013-47761, KAVIENG 2014, St. KB08, 2³3'S; 15048'E, 13 m, 17.8 mm.

Figure 4. A, B. Clavus exasperatus. A. Probable holotype NHMUK 1966462, Cuming collection, locality unknown, 23.7 mm; B. MNHN-IM-2009-19172, PANGLAO 2004, St. B9, $9^{\circ} 33^{\prime} \mathrm{N}$; 123ํㄴ' E, 8-10 m, 17.9 mm. C - E. Clavus brianmayi. C, D, Holotype, MNHN-IM2013-85593, KOUMAC 2.1 St. KR643, 2045'S; 164¹6'E, 7 m; E. Loyalty Islands, LIFOU 2000, St. 1422, 2047.1'S; 16707.4'E, 4 m, 27.7 mm. F. Clavus groschi holotype NMSA G3034/T3583, North Mozambique, Conducia Bay, 1456'S, 4041'E, intertidal, 22.8 mm; G - I. Clavus davidgilmouri; G, H. Holotype, MNHN-IM-2013-86068, Philippines, off N. Olango Is, 15-25 m, 25.4 mm; I. Paratype 1. MNHN-IM-2013-86070, same locality as holotype; J - L. Clavus andreolbrichi; J, K. Holotype MNHN-IM-2013-54871, KAVIENG 2014, St. KZ02, 
$2^{\circ} 37$ 'S; 15044'E, 9 m, 26 mm; L. MNHN-IM-2007-42576, SANTO 2006, St. FR30, 15²7'S; $167^{\circ} 16^{\prime} \mathrm{E}, 0-45 \mathrm{~m}, 25.73 \mathrm{~mm}$. M. Drillia sikesi, holotype, ZSI M4003, Andaman Is., 30.9 mm.

Figure 5. A - C. Clavus kirkhammetti. A, B. Holotype MNHN-IM-2009-14898, ATIMO

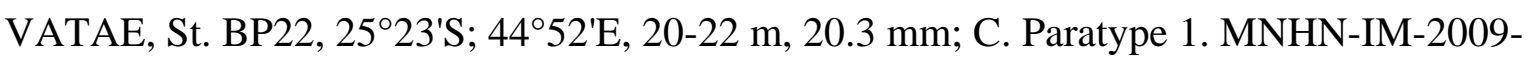

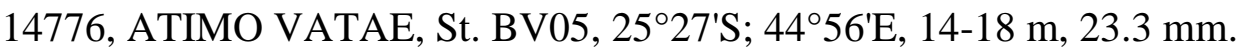




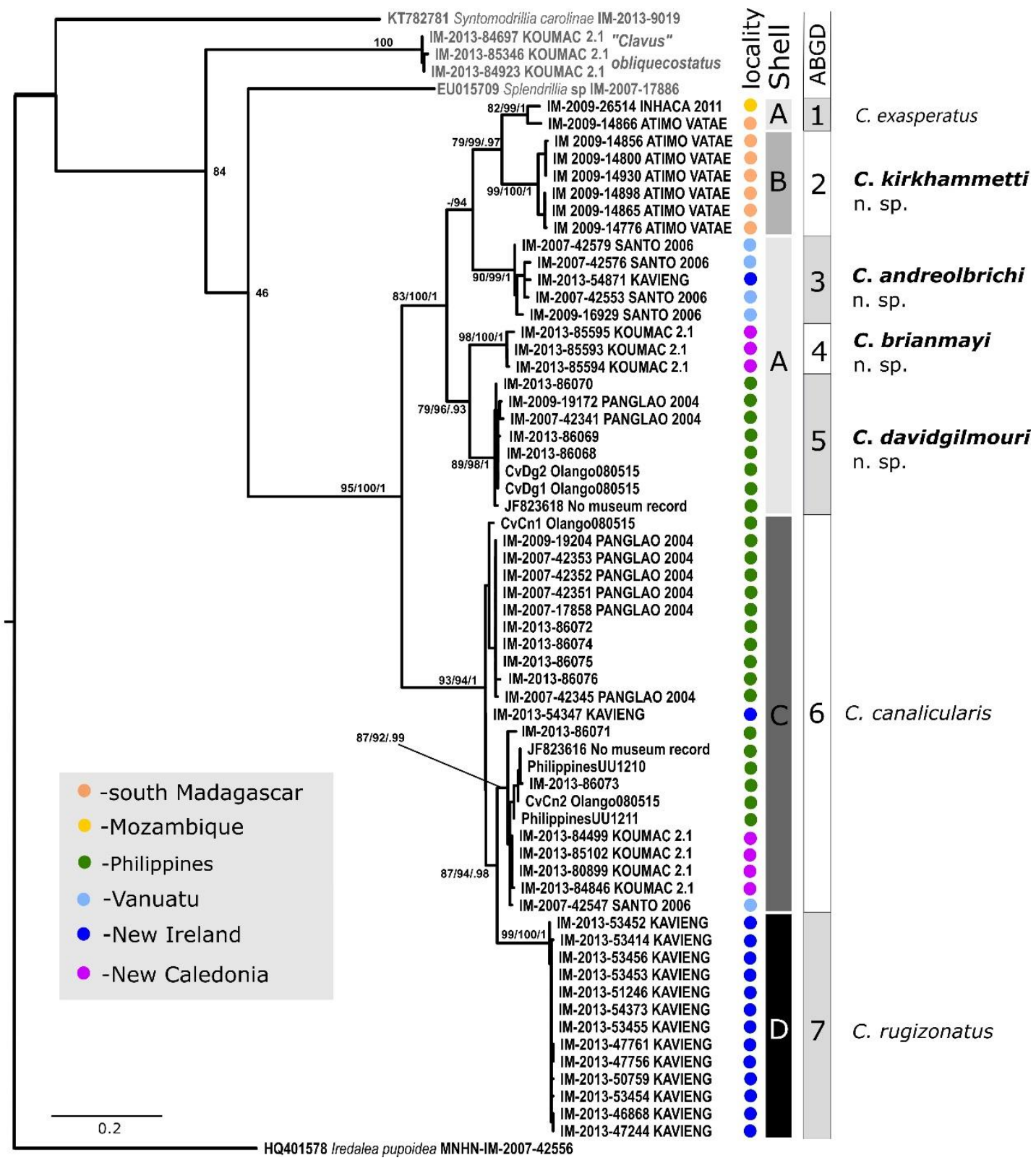

Figure 1. 


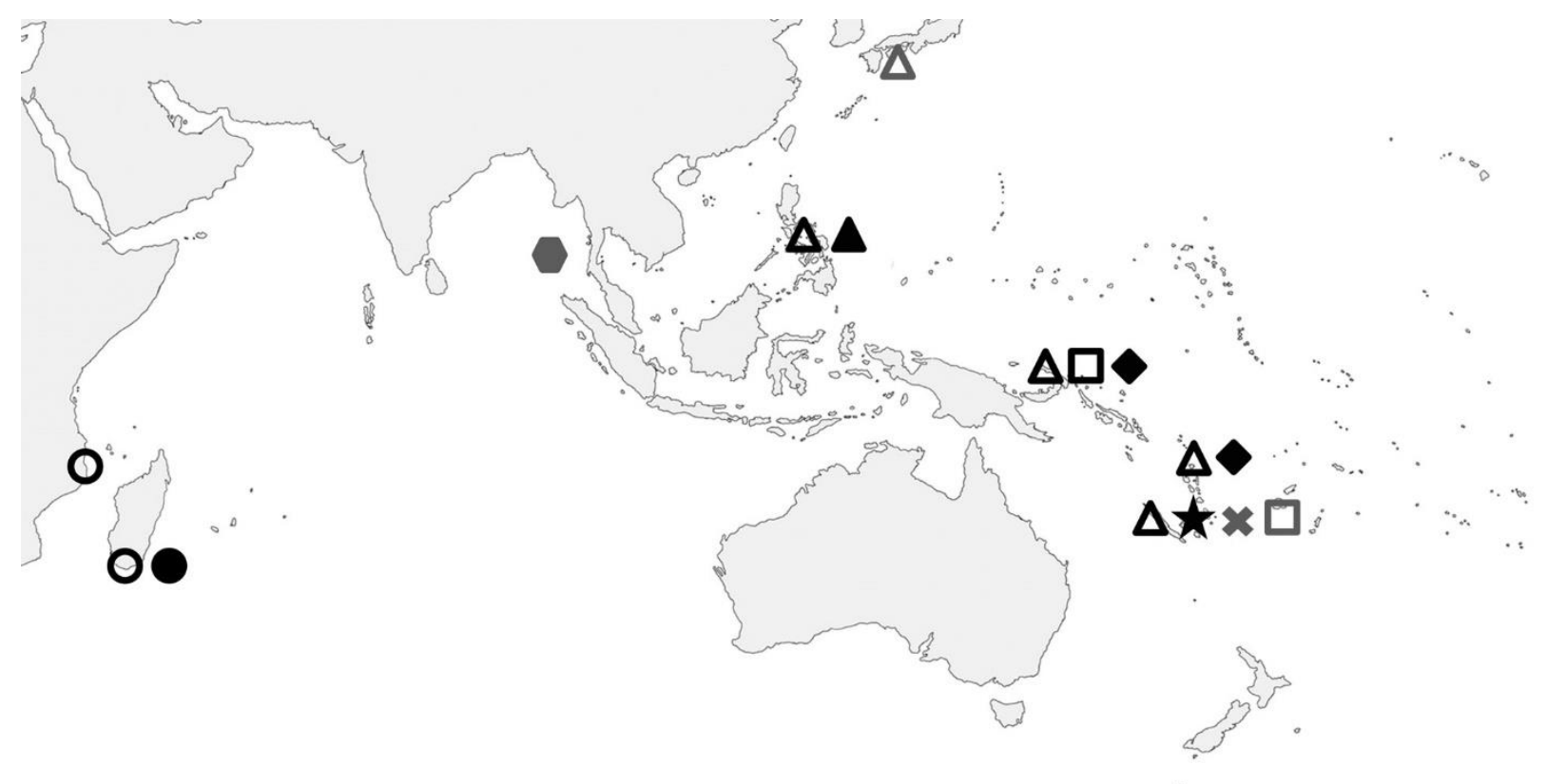

Figure 2.

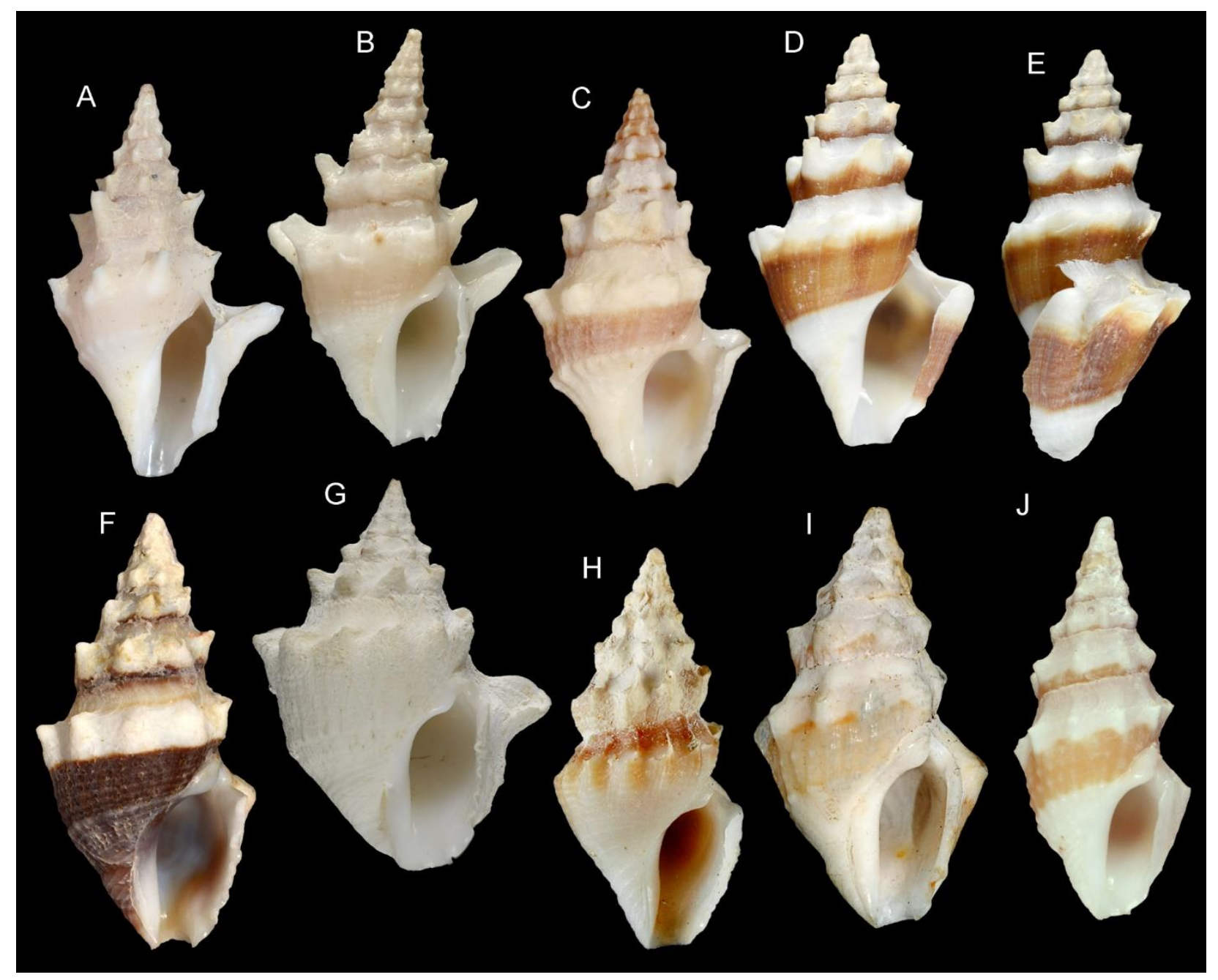

Figure 3. 


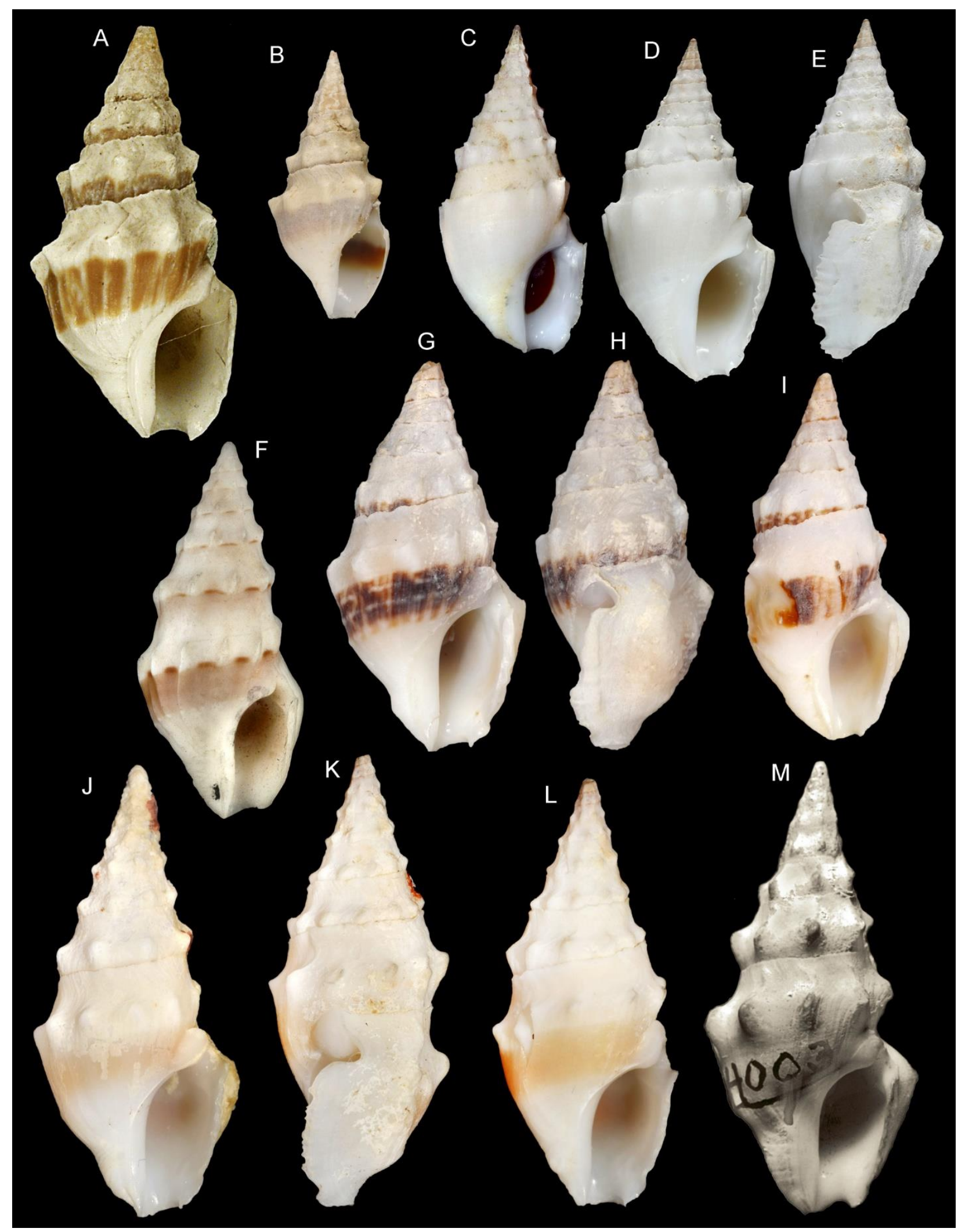

Figure 4. 


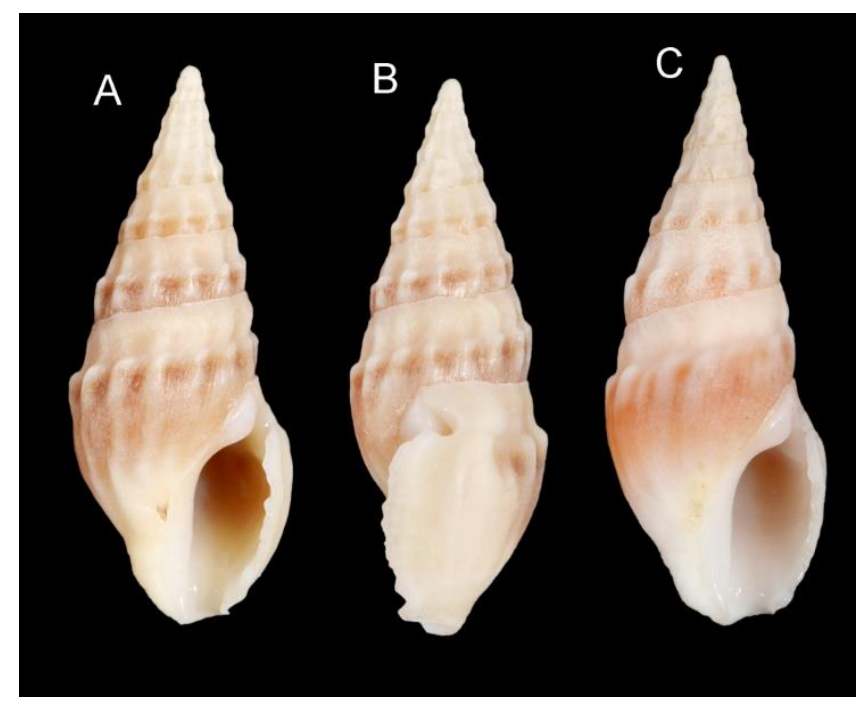

Figure 5. 
Table 1. Specimens used in the phylogenetic analysis.

\begin{tabular}{|c|c|c|c|c|c|c|c|}
\hline Specimen ID & Expedition & Station & Coordinates, depth / Locality & Genus & species & BOLD & $\mathrm{COI} G \mathrm{~B}$ \\
\hline MNHN-IM-2013-46868 & KAVIENG 2014 & KR04 & $2^{\circ} 35^{\prime} \mathrm{S} ; 150^{\circ} 46^{\prime} \mathrm{E}, 6-22 \mathrm{~m}$ & Clavus & rugizonatus & CONO3106-20 & MT456806 \\
\hline MNHN-IM-2013-47244 & KAVIENG 2014 & KS03 & $2^{\circ} 34^{\prime} \mathrm{S} ; 150^{\circ} 47^{\prime} \mathrm{E}, 8-10 \mathrm{~m}$ & Clavus & rugizonatus & CONO3107-20 & MT456783 \\
\hline MNHN-IM-2013-47756 & KAVIENG 2014 & KS11 & $2^{\circ} 33^{\prime} \mathrm{S} ; 150^{\circ} 48^{\prime} \mathrm{E}, 7 \mathrm{~m}$ & Clavus & rugizonatus & CONO3114-20 & MT456801 \\
\hline MNHN-IM-2013-47761 & KAVIENG 2014 & KB08 & $2^{\circ} 33^{\prime} \mathrm{S} ; 150^{\circ} 48^{\prime} \mathrm{E}, 13 \mathrm{~m}$ & Clavus & rugizonatus & CONO3115-20 & MT456778 \\
\hline MNHN-IM-2013-50759 & KAVIENG 2014 & KS21 & $2^{\circ} 35^{\prime} \mathrm{S} ; 150^{\circ} 46^{\prime} \mathrm{E}, 4 \mathrm{~m}$ & Clavus & rugizonatus & CONO3118-20 & MT456787 \\
\hline MNHN-IM-2013-51246 & KAVIENG 2014 & KR54 & $2^{\circ} 42^{\prime} \mathrm{S} ; 150^{\circ} 39^{\prime} \mathrm{E}, 7-10 \mathrm{~m}$ & Clavus & rugizonatus & CONO3120-20 & MT456775 \\
\hline MNHN-IM-2013-53414 & KAVIENG 2014 & KZO2 & $2^{\circ} 37^{\prime} \mathrm{S} ; 150^{\circ} 44^{\prime} \mathrm{E}, 9 \mathrm{~m}$ & Clavus & rugizonatus & CONO3108-20 & MT456765 \\
\hline MNHN-IM-2013-53452 & KAVIENG 2014 & KR70 & $2^{\circ} 40^{\prime} \mathrm{S} ; 150^{\circ} 39^{\prime} \mathrm{E}, 9-11 \mathrm{~m}$ & Clavus & rugizonatus & CONO3109-20 & MT456799 \\
\hline MNHN-IM-2013-53453 & KAVIENG 2014 & KR70 & $2^{\circ} 40^{\prime} \mathrm{S} ; 150^{\circ} 39^{\prime} \mathrm{E}, 9-11 \mathrm{~m}$ & Clavus & rugizonatus & CONO3110-20 & MT456798 \\
\hline MNHN-IM-2013-53454 & KAVIENG 2014 & KR70 & $2^{\circ} 40^{\prime} \mathrm{S} ; 150^{\circ} 39^{\prime} \mathrm{E}, 9-11 \mathrm{~m}$ & Clavus & rugizonatus & CONO3111-20 & MT456793 \\
\hline MNHN-IM-2013-53455 & KAVIENG 2014 & KR70 & $2^{\circ} 40^{\prime} \mathrm{S} ; 150^{\circ} 39^{\prime} \mathrm{E}, 9-11 \mathrm{~m}$ & Clavus & rugizonatus & CONO3112-20 & MT456792 \\
\hline MNHN-IM-2013-53456 & KAVIENG 2014 & KR70 & $2^{\circ} 40^{\prime} \mathrm{S} ; 150^{\circ} 39^{\prime} \mathrm{E}, 9-11 \mathrm{~m}$ & Clavus & rugizonatus & CONO3113-20 & MT456808 \\
\hline MNHN-IM-2013-54373 & KAVIENG 2014 & KB46 & $2^{\circ} 35^{\prime} \mathrm{S} ; 150^{\circ} 33^{\prime} \mathrm{E}, 8 \mathrm{~m}$ & Clavus & rugizonatus & CONO3117-20 & MT456776 \\
\hline MNHN-IM-2013-54347 & KAVIENG 2014 & KR102 & $2^{\circ} 38^{\prime} \mathrm{S} ; 150^{\circ} 27^{\prime} \mathrm{E}, 3-18 \mathrm{~m}$ & Clavus & canalicularis & CONO3116-20 & MT456769 \\
\hline MNHN-IM-2009-19204 & PANGLAO 2004 & $\mathrm{~S} 12$ & $9^{\circ} 29^{\prime} \mathrm{N} ; 123^{\circ} 56^{\prime} \mathrm{E}, 6-8 \mathrm{~m}$ & Clavus & canalicularis & CONO3103-20 & MT456770 \\
\hline MNHN-IM-2007-42345 & PANGLAO 2004 & B11 & $9^{\circ} 29^{\prime} \mathrm{N} ; 123^{\circ} 56^{\prime} \mathrm{E}, 2-4 \mathrm{~m}$ & Clavus & canalicularis & CONO616-08 & MT456773 \\
\hline MNHN-IM-2007-42351 & PANGLAO 2004 & S12 & $9^{\circ} 29^{\prime} \mathrm{N} ; 123^{\circ} 56^{\prime} \mathrm{E}, 6-8 \mathrm{~m}$ & Clavus & canalicularis & CONO622-08 & MT456804 \\
\hline MNHN-IM-2007-42352 & PANGLAO 2004 & S12 & $9^{\circ} 29^{\prime} \mathrm{N} ; 123^{\circ} 56^{\prime} \mathrm{E}, 6-8 \mathrm{~m}$ & Clavus & canalicularis & CONO623-08 & MT456762 \\
\hline MNHN-IM-2007-42353 & PANGLAO 2004 & $\mathrm{~S} 12$ & $9^{\circ} 29^{\prime} \mathrm{N} ; 123^{\circ} 56^{\prime} \mathrm{E}, 6-8 \mathrm{~m}$ & Clavus & canalicularis & CONO624-08 & MT456766 \\
\hline MNHN-IM-2007-42547 & SANTO 2006 & DS10 & $15^{\circ} 37^{\prime} \mathrm{S} ; 167^{\circ} 10^{\prime} \mathrm{E}, 6-24 \mathrm{~m}$ & Clavus & canalicularis & CONO864-08 & MT456810 \\
\hline MNHN-IM-2009-19172 & PANGLAO 2004 & B9 & $9^{\circ} 33^{\prime} \mathrm{N} ; 123^{\circ} 44^{\prime} \mathrm{E}, 8-10 \mathrm{~m}$ & Clavus & davidgilmouri & CONO3102-20 & MT456785 \\
\hline MNHN-IM-2007-42341 & PANGLAO 2004 & B9 & $9^{\circ} 33^{\prime} \mathrm{N} ; 123^{\circ} 44^{\prime} \mathrm{E}, 8-10 \mathrm{~m}$ & Clavus & davidgilmouri & CONO612-08 & MT456763 \\
\hline MNHN-IM-2009-14866 & ATIMO VATAE & TSO2 & $25^{\circ} 1 \mathrm{~S} ; 47^{\circ} \mathrm{O}^{\prime} \mathrm{E}, 18 \mathrm{~m}$ & Clavus & exasperatus & CONO3100-20 & MT456779 \\
\hline MNHN-IM-2009-26514 & INHACA 2011 & MSO2 & $26^{\circ} 6^{\prime} \mathrm{S} ; 32^{\circ} 58^{\prime} \mathrm{E}, 17-19 \mathrm{~m}$ & Clavus & exasperatus & CONO3105-20 & MT456774 \\
\hline MNHN-IM-2013-54871 & KAVIENG 2014 & KZO2 & $2^{\circ} 37^{\prime} \mathrm{S} ; 150^{\circ} 44^{\prime} \mathrm{E}, 9 \mathrm{~m}$ & Clavus & andreolbrichi & CONO3119-20 & MT456812 \\
\hline
\end{tabular}


MNHN-IM-2007-42553 MNHN-IM-2007-42576 MNHN-IM-2007-42579 MNHN-IM-2009-16929 MNHN-IM-2007-17858 MNHN-IM-2009-14776 MNHN-IM-2009-14800 MNHN-IM-2009-14856 MNHN-IM-2009-14865 MNHN-IM-2009-14898 MNHN-IM-2009-14930 MNHN-IM-2013-85593 MNHN-IM-2013-85594 MNHN-IM-2013-85595 MNHN-IM-2013-80899 MNHN-IM-2013-85102 MNHN-IM-2013-84499 MNHN-IM-2013-84846 UU1211

UU1210

CvCn1

$\mathrm{CvCn} 2$

CvDg1

CvDg2

MNHN-IM-2013-86068 MNHN-IM-2013-86069 MNHN-IM-2013-86070 MNHN-IM-2013-86071 MNHN-IM-2013-86072

\begin{tabular}{|c|c|c|c|c|c|c|}
\hline SANTO 2006 & NR08 & $15^{\circ} 36^{\prime} \mathrm{S} ; 167^{\circ} 7^{\prime} \mathrm{E}, 11 \mathrm{~m}$ & Clavus & andreolbrichi & CONO870-08 & MT456789 \\
\hline SANTO 2006 & FR30 & $15^{\circ} 27^{\prime} \mathrm{S} ; 167^{\circ} 16^{\prime} \mathrm{E}, 0-45 \mathrm{~m}$ & Clavus & andreolbrichi & CONO893-08 & MT456788 \\
\hline SANTO 2006 & DR68 & $15^{\circ} 23^{\prime} \mathrm{S} ; 167^{\circ} 13^{\prime} \mathrm{E}, 7-27 \mathrm{~m}$ & Clavus & andreolbrichi & CONO896-08 & MT456802 \\
\hline SANTO 2006 & DR52 & NO DATA & Clavus & andreolbrichi & CONO3095-20 & MT456780 \\
\hline PANGLAO 2004 & S12 & $9^{\circ} 29^{\prime} \mathrm{N} ; 123^{\circ} 56^{\prime} \mathrm{E}, 6-8 \mathrm{~m}$ & Clavus & canalicularis & CONO229-08 & EU015680 \\
\hline ATIMO VATAE & BV05 & $25^{\circ} 27^{\prime} \mathrm{S} ; 44^{\circ} 56^{\prime} \mathrm{E}, 14-18 \mathrm{~m}$ & Clavus & kirkhammetti & CONO3097-20 & MT456767 \\
\hline ATIMO VATAE & CP3603 & $25^{\circ} 57^{\prime} \mathrm{S} ; 44^{\circ} 48^{\prime} \mathrm{E}, 62-63 \mathrm{~m}$ & Clavus & kirkhammetti & CONO3096-20 & MT456803 \\
\hline ATIMO VATAE & BP21 & $25^{\circ} 23^{\prime} \mathrm{S} ; 44^{\circ} 52^{\prime} \mathrm{E}, 20-23 \mathrm{~m}$ & Clavus & kirkhammetti & CONO3101-20 & MT456781 \\
\hline ATIMO VATAE & $\mathrm{BSO4}$ & $25^{\circ} 27^{\prime} \mathrm{S} ; 44^{\circ} 56^{\prime} \mathrm{E}, 14-18 \mathrm{~m}$ & Clavus & kirkhammetti & CONO3098-20 & MT456805 \\
\hline ATIMO VATAE & BP22 & $25^{\circ} 23^{\prime} \mathrm{S} ; 44^{\circ} 52^{\prime} \mathrm{E}, 20-22 \mathrm{~m}$ & Clavus & kirkhammetti & CONO3099-20 & MT456761 \\
\hline ATIMO VATAE & CP3624 & $25^{\circ} 38^{\prime} \mathrm{S} ; 45^{\circ} 57^{\prime} \mathrm{E}, 63 \mathrm{~m}$ & Clavus & kirkhammetti & CONO3104-20 & MT456791 \\
\hline KOUMAC 2.1 & KR643 & $20^{\circ} 45^{\prime} \mathrm{S} ; 164^{\circ} 16^{\prime} \mathrm{E}, 7 \mathrm{~m}$ & Clavus & brianmayi & CONO3137-20 & MT456811 \\
\hline KOUMAC 2.1 & KR643 & $20^{\circ} 45^{\prime} \mathrm{S} ; 164^{\circ} 16^{\prime} \mathrm{E}, 7 \mathrm{~m}$ & Clavus & brianmayi & CONO3138-20 & MT456772 \\
\hline KOUMAC 2.1 & KR643 & $20^{\circ} 45^{\prime} \mathrm{S} ; 164^{\circ} 16^{\prime} \mathrm{E}, 7 \mathrm{~m}$ & Clavus & brianmayi & CONO3139-20 & MT456809 \\
\hline KOUMAC 2.1 & KR625 & $20^{\circ} 35^{\prime} \mathrm{S} ; 164^{\circ} 16^{\prime} \mathrm{E}, 8 \mathrm{~m}$ & Clavus & canalicularis & CONO3133-20 & MT456813 \\
\hline KOUMAC 2.1 & KR625 & $20^{\circ} 35^{\prime} \mathrm{S} ; 164^{\circ} 16^{\prime} \mathrm{E}, 8 \mathrm{~m}$ & Clavus & canalicularis & CONO3130-20 & MT456790 \\
\hline KOUMAC 2.1 & KR634 & $20^{\circ} 46^{\prime} \mathrm{S} ; 164^{\circ} 19^{\prime} \mathrm{E}, 18 \mathrm{~m}$ & Clavus & canalicularis & CONO3131-20 & MT456797 \\
\hline \multirow[t]{12}{*}{ KOUMAC 2.1} & KR218 & $20^{\circ} 36^{\prime} \mathrm{S} ; 164^{\circ} 10^{\prime} \mathrm{E}, 11 \mathrm{~m}$ & Clavus & canalicularis & CONO3132-20 & MT456784 \\
\hline & & Philippines, off N. Olango Is, $15-25 \mathrm{~m}$ & Clavus & canalicularis & - & $x X x$ \\
\hline & & Philippines, off N. Olango Is, $15-25 \mathrm{~m}$ & Clavus & canalicularis & - & $x X X$ \\
\hline & & Philippines, off N. Olango Is, $15-25 \mathrm{~m}$ & Clavus & canalicularis & - & PRJNA610292 \\
\hline & & Philippines, off N. Olango Is, $15-25 \mathrm{~m}$ & Clavus & canalicularis & - & PRJNA610292 \\
\hline & & Philippines, off N. Olango Is, $15-25 \mathrm{~m}$ & Clavus & davidgilmouri & - & PRJNA610292 \\
\hline & & Philippines, off N. Olango Is, $15-25 \mathrm{~m}$ & Clavus & davidgilmouri & - & PRJNA610292 \\
\hline & & Philippines, off N. Olango Is, $15-25 \mathrm{~m}$ & Clavus & davidgilmouri & CONO3121-20 & MT456777 \\
\hline & & Philippines, off N. Olango Is, $15-25 \mathrm{~m}$ & Clavus & davidgilmouri & CONO3122-20 & MT456764 \\
\hline & & Philippines, off N. Olango Is, $15-25 \mathrm{~m}$ & Clavus & davidgilmouri & CONO3123-20 & MT456795 \\
\hline & & Philippines, off N. Olango Is, $15-25 \mathrm{~m}$ & Clavus & canalicularis & CONO3124-20 & MT456796 \\
\hline & & Philippines, off N. Olango Is, $15-25 \mathrm{~m}$ & Clavus & canalicularis & CONO3125-20 & MT456786 \\
\hline
\end{tabular}




\begin{tabular}{|c|c|c|c|c|c|c|c|}
\hline MNHN-IM-2013-86073 & & & Philippines, off N. Olango Is, $15-25 \mathrm{~m}$ & Clavus & canalicularis & CONO3126-20 & MT456794 \\
\hline MNHN-IM-2013-86074 & & & Philippines, off N. Olango Is, $15-25 \mathrm{~m}$ & Clavus & canalicularis & CONO3127-20 & MT456782 \\
\hline MNHN-IM-2013-86075 & & & Philippines, off N. Olango Is, $15-25 \mathrm{~m}$ & Clavus & canalicularis & CONO3128-20 & MT456760 \\
\hline MNHN-IM-2013-86076 & & & Philippines, off N. Olango Is, $15-25 \mathrm{~m}$ & Clavus & canalicularis & CONO3129-20 & MT456771 \\
\hline No_museum_record & & & NO DATA & Clavus & canalicularis & - & JF823616 \\
\hline No_museum_record & & & NO DATA & Clavus & davidgilmouri & - & JF823618 \\
\hline \multicolumn{8}{|l|}{ OUTGROUPS } \\
\hline MNHN-IM-2013-84923 & KOUMAC 2.1 & KR218 & $20^{\circ} 36^{\prime} \mathrm{S} ; 164^{\circ} 10^{\prime} \mathrm{E}, 11 \mathrm{~m}$ & Clavus' & obliquecostatus & CONO3135-20 & MT456768 \\
\hline MNHN-IM-2013-84697 & KOUMAC 2.1 & KR621 & $20^{\circ} 32^{\prime} \mathrm{S} ; 164^{\circ} 04^{\prime} \mathrm{E}, 7 \mathrm{~m}$ & Clavus' & obliquecostatus & CONO3134-20 & MT456800 \\
\hline MNHN-IM-2013-85346 & KOUMAC 2.1 & KM318 & $20^{\circ} 36^{\prime} \mathrm{S} ; 164^{\circ} 13^{\prime} \mathrm{E}, 0 \mathrm{~m}$ & Clavus' & obliquecostatus & CONO3136-20 & MT456807 \\
\hline MNHN-IM-2007-17886 & $\begin{array}{l}\text { PANGLAO } 2004 \\
\text { KARUBENTHOS }\end{array}$ & T36 & $9^{\circ} 29^{\prime} \mathrm{N} ; 123^{\circ} 52^{\prime} \mathrm{E}, 95-128 \mathrm{~m}$ & Splendrillia & $s p$ & CONO274-08 & EU015709 \\
\hline MNHN-IM-2013-9019 & 2012 & GD31 & $16^{\circ} 24^{\prime} \mathrm{N} ; 61^{\circ} 32^{\prime} \mathrm{W}, 85 \mathrm{~m}$ & Splendrillia & carolinae & TEMPO016-15 & KT782781 \\
\hline MNHN-IM-2007-42556 & SANTO 2006 & DB25 & $15^{\circ} 37^{\prime} \mathrm{S} ; 167^{\circ} 11^{\prime} \mathrm{E}, 10 \mathrm{~m}$ & Iredalea & pupoidea & CONO873-08 & HQ401578 \\
\hline
\end{tabular}


Table 2. Comparison of species in the C. canalicularis complex.

\begin{tabular}{|c|c|c|c|c|c|}
\hline SSH & $\begin{array}{l}\text { Morphological } \\
\text { cluster }\end{array}$ & $\begin{array}{l}\text { Shape of sculptural } \\
\text { elements }\end{array}$ & $\begin{array}{l}\text { Position of sculptural } \\
\text { elements on spire whorls }\end{array}$ & Sculpture / coloration of the shell base & Species \\
\hline 1 & A & $\begin{array}{l}\text { Axially elongated, weakly } \\
\text { squamose nodes }\end{array}$ & At mid-height & Wide rounded axial folds / light-brown band & C. exasperatus \\
\hline 2 & B & $\begin{array}{l}\text { Axially elongated, rounded } \\
\text { folds }\end{array}$ & $\begin{array}{l}\text { Throughout whorl's } \\
\text { height }\end{array}$ & No sculpture / no band & $\begin{array}{l}\text { C. kirkhammetti n. } \\
\text { sp. }\end{array}$ \\
\hline 3 & $A$ & $\begin{array}{l}\text { Prominent, rounded, not } \\
\text { Squamose nodes }\end{array}$ & At lower suture & No sculpture, light-orange band & $\begin{array}{l}\text { C. andreolbrichi n. } \\
\text { sp. }\end{array}$ \\
\hline 4 & $A$ & Squamose nodes & At mid-height & No sculpture / no band & C. brianmayi n. sp. \\
\hline 5 & $A$ & $\begin{array}{l}\text { Prominent, rounded, not } \\
\text { squamose nodes }\end{array}$ & At lower suture & $\begin{array}{l}\text { Dark-brown band / spirally elongated nodules, } \\
\text { merged into undulating cords }\end{array}$ & $\begin{array}{l}\text { C. davidgilmouri n. } \\
\text { sp. }\end{array}$ \\
\hline 6 & C & $\begin{array}{l}\text { Prominent, squamose } \\
\text { nodes, often spinose }\end{array}$ & At mid-height & $\begin{array}{c}\text { Varying coloration / spiral grooves, sometimes row } \\
\text { of sharp tubercles }\end{array}$ & C. canalicularis \\
\hline 7 & D & Squamose nodes & $\begin{array}{l}\text { At or slightly below mid- } \\
\text { height }\end{array}$ & $\begin{array}{c}\text { Orange or light-brown band boardered by darker } \\
\text { spiral line / several spirally aligned rows of minute, } \\
\text { rounded nodules }\end{array}$ & C. rugizonatus \\
\hline- & - & Squamose nodes & At mid-height & Light band / wie flattened cords & C. devexistriatus \\
\hline
\end{tabular}

